Nat. Hazards Earth Syst. Sci., 17, 2365-2381, 2017

https://doi.org/10.5194/nhess-17-2365-2017

(C) Author(s) 2017. This work is distributed under

the Creative Commons Attribution 3.0 License.

\title{
Planar seismic source characterization models developed for probabilistic seismic hazard assessment of Istanbul
}

\author{
Zeynep Gülerce ${ }^{1}$, Kadir Buğra Soyman ${ }^{1}$, Barış Güner $^{2}$, and Nuretdin Kaymakci ${ }^{3}$ \\ ${ }^{1}$ Department of Civil Engineering, Middle East Technical University, Ankara, 06800, Turkey \\ ${ }^{2}$ Department of Nuclear Safety, Turkish Atomic Energy Authority, Ankara, 06510, Turkey \\ ${ }^{3}$ Department of Geological Engineering, Middle East Technical University, Ankara, 06800, Turkey
}

Correspondence: Zeynep Gülerce (zyilmaz@metu.edu.tr)

Received: 27 March 2017 - Discussion started: 2 May 2017

Revised: 9 October 2017 - Accepted: 19 October 2017 - Published: 22 December 2017

\begin{abstract}
This contribution provides an updated planar seismic source characterization (SSC) model to be used in the probabilistic seismic hazard assessment (PSHA) for Istanbul. It defines planar rupture systems for the four main segments of the North Anatolian fault zone (NAFZ) that are critical for the PSHA of Istanbul: segments covering the rupture zones of the 1999 Kocaeli and Düzce earthquakes, central Marmara, and Ganos/Saros segments. In each rupture system, the source geometry is defined in terms of fault length, fault width, fault plane attitude, and segmentation points. Activity rates and the magnitude recurrence models for each rupture system are established by considering geological and geodetic constraints and are tested based on the observed seismicity that is associated with the rupture system. Uncertainty in the SSC model parameters (e.g., $b$ value, maximum magnitude, slip rate, weights of the rupture scenarios) is considered, whereas the uncertainty in the fault geometry is not included in the logic tree. To acknowledge the effect of earthquakes that are not associated with the defined rupture systems on the hazard, a background zone is introduced and the seismicity rates in the background zone are calculated using smoothed-seismicity approach. The state-of-the-art SSC model presented here is the first fully documented and readyto-use fault-based SSC model developed for the PSHA of Istanbul.
\end{abstract}

\section{Introduction}

The North Anatolian fault zone (NAFZ), one of the most active fault systems in the world, extends for more than $1500 \mathrm{~km}$ along northern Turkey (Fig. 1b). NAFZ was ruptured progressively by eight large and destructive earthquakes $\left(M_{\mathrm{w}}>6.5\right)$ in the last century. Earthquakes that occurred between 1939 and 1967 had ruptured approximately $900 \mathrm{~km}$ of a uniform trace in the east, whereas the 1999 Kocaeli and Düzce earthquakes ruptured a total fault span of approximately $200 \mathrm{~km}$ where the NAFZ is divided into a number of branches in the west. The northern strand of the NAFZ is submerged beneath the Marmara Sea to the west of the rupture zone of the 1999 Kocaeli earthquake, introducing major uncertainties into segment location, continuity, and earthquake recurrence (Fig. 1a). In 2004, Parsons compiled a catalog of large-magnitude $(M>7)$ earthquakes occurred around the Marmara Sea for the time period of AD 1500-2000. Based on the rupture zones of these large-magnitude events, four main segments for the northern strand of the NAFZ around Marmara Sea were proposed by Parsons (2004): (1) the Ganos segment, which combines the rupture zones of August 1776 and 1912 earthquakes; (2) the Prince Island segment, which includes the rupture zones of 1509 and May 1766 earthquakes; (3) the Izmit segment, defined for the rupture zones of the 1719 and 1999 earthquakes; and (4) the Çınarcık segment, defined for $M \sim 7$ floating earthquakes (independent normal-fault earthquakes that may have occurred on different fault segments in or around the Çınarcık Basin). Parsons (2004) noted that 10 May 1556 $\left(M_{\mathrm{S}}=7.1\right), 2$ September $1754(M=7.0)$, and 10 July 1894 $(M=7.0)$ earthquakes were assigned locations in the Çınar- 


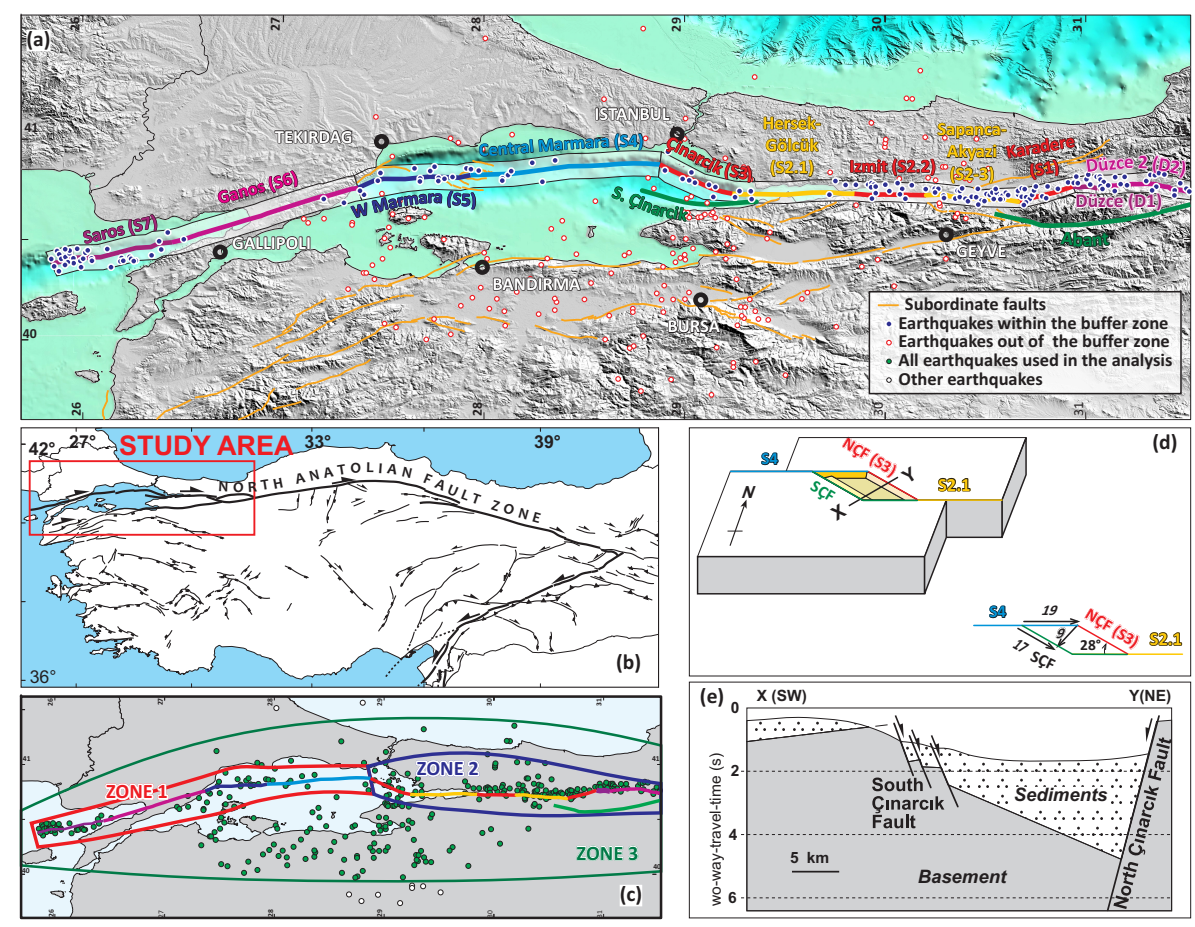

Figure 1. (a) Major branches of the North Anatolian fault zone, defined rupture systems and the instrumental seismicity $\left(M_{\mathrm{W}}>4\right)$ in the study area. The buffer zones used for source-to-epicenter matching are shown around the rupture systems. (b) Simplified active tectonic scheme of Turkey (modified from Emre et al., 2013). Thick lines are the North Anatolian and East Anatolian fault zones; thin lines are other active faults. (c) Distribution of the declustered seismicity used to calculate the $b$ values. Zone 1, Zone 2 and Zone 3 are the polygons used to calculate the $b$ values. (d) Slip distribution model for the Çınarcık segment. Right bending of the northern Çınarcık segment is $28^{\circ}$ with respect to the central Marmara and Hersek-Gölcük segments. This results in a $17 \mathrm{~mm} \mathrm{yr}^{-1}$ slip along the northern Çınarcık segment (NÇF) and $9 \mathrm{~mm} \mathrm{yr}^{-1}$ normal slip transverse to the fault. This $9 \mathrm{~mm} \mathrm{yr}^{-1}$ slip is the total slip on the northern and southern Çınarcık faults (SÇF). (e) Simplified geometries of the Çınarcık faults delimiting the Çınarcık Basin based on seismic profile of Laigle et al. (2008) almost passing through the line $X Y$.

c1k Basin or on mapped normal faults in the southern parts of the Marmara Sea. These events were not allocated to the other segments in order not to violate the inter-event time calculations, although they could have occurred on the northern strand of the NAFZ.

The fault segmentation model proposed by Erdik et al. (2004) was similar to the segmentation model proposed by Parsons (2004) in terms of the fault geometry; however, smaller segments were preferred. Erdik et al. (2004) noted that "the Main Marmara Fault cuts through Çınarcık, central and Tekirdağ basins, follows the northern margin of the basin when going through the Çinarcik trough in the northwesterly direction, makes a westwards kink around south of Yeşilkoy until it reaches the 1912 Murefte-Şarköy rupture". All of these fault lines were interpreted as separate fault segments in the segmentation model. Erdik et al. (2004) considered multi-segment ruptures by assigning lower probabilities to "cascading ruptures". Based on the rupture zones of previous large-magnitude events, multi-segment ruptures involving the segments in connection with the 1999 Kocaeli earthquake and 1509 earthquake were included in the rupture forecast. Even though multi-segment ruptures were considered, the relative probabilities of the multi-segment ruptures vs. single-segment ruptures were not systematically defined in Erdik et al. (2004). This seismic source model was updated for the Earthquake Hazard Assessment for Istanbul project by OYO (2007). The fundamental differences between the Erdik et al. (2004) and OYO-2007 models are (1) small segments around Marmara Sea used in the Erdik et al. (2004) model were combined to form bigger segments in the OYO2007 model, (2) fault segments that represent the floating earthquakes were defined. The segmentation model used in OYO-2007 source characterization is very similar to the segmentation model proposed by Parsons (2004).

The fault segmentation model used by Kalkan et al. (2009) includes significant differences in terms of the fault geometry with the Erdik et al. (2004) model, even though both studies used the active fault maps of Şaroğlu et al. (1992) for inland faults and the fault segmentation model from Le Pichon et al. (2003) and Armijo et al. (2005) for the segments beneath the Sea of Marmara. On the other hand, the magnitude recurrence models used by Erdik et al. (2004), in the 
OYO-2007 model, and by Kalkan et al. (2009) were rather similar. In all of these studies, linear fault segments were modeled (fully or partially) by the characteristic model proposed by Schwartz and Coppersmith (1984); therefore, only large-magnitude events were associated with the fault segments. Additionally, a background source representing the small-to-moderate magnitude earthquakes (earthquakes between 5 and 6.5-7 depending on the study) were added to the source model and the earthquake recurrence of the background source was modeled using a double-truncated exponential magnitude distribution model. Either the Poisson (Erdik et al., 2004; Kalkan et al., 2009) or time-dependent renewal (Brownian Passage Time, Ellsworth et al., 1999) model (Erdik et al., 2004) was chosen to model the earthquake recurrence rates for linear segments, whereas the Poisson distribution was used to model the recurrence rates of the background source in these studies.

Recently proposed SSC models for the western segments of the NAFZ (Gülerce and Ocak, 2013; Murru et al., 2016) are more detailed in terms of the segmentation models, magnitude recurrence relations, and estimation of the activity rates. In the Gülerce and Ocak (2013) SSC model, the length of segments and the segmentation points were determined and incorporated with the help of then-available fault maps and traced source lines on the satellite images. Planar fault segments were defined and the composite magnitude distribution model (Youngs and Coppersmith, 1985) was used for all seismic sources to properly represent the characteristic behavior of the NAFZ without an additional background zone. Unfortunately, the seismic source model proposed by Gülerce and Ocak (2013) cannot be directly implemented in the PSHA for Istanbul since the model does not include the fault segments on the west of the 1999 Kocaeli earthquake rupture zone. The geometry of the fault segments defined in Murru et al. (2016) is generally similar to the Erdik et al. (2004) model. Furthermore, Murru et al. (2016) provided the complete set of parameters required for a faultbased PSHA analysis (e.g., slip rates, fault widths, rupture models and rates, parameter uncertainties).

The objective of this study is to provide an updated and properly documented fault-based SSC model to be used in the PSHA studies in Istanbul. A significant portion of the tectonic database is acquired from the updated Active Fault Map of Turkey that was published by General Directorate of Mineral Research and Exploration (Emre et al., 2013) (accessed through http://www.mta.gov.tr/v3. 0/hizmetler/yenilenmis-diri-fay-haritalari). The 1/250000 scale Çanakkale (NK 35-10b), Bandırma (NK 35-11b), Bursa (NK 35-12), Adapazarı (NK 36-13), Bolu (NK 3614), and Istanbul (NK 35-9) sheets of updated Active Fault Map of Turkey were accessed and digitized. The seismological database is taken from the Integrated and Homogeneous Turkish Earthquake Catalog published by the Kandilli Observatory and Earthquake Research Institute (Kalafat et al., 2011). Seismotectonic information related to the active faults and the fault systems that are available in these databases and in the current scientific literature are used in combination with the segmentation models proposed by Gülerce and Ocak (2013) and Murru et al. (2016) to define the rupture systems. Fault segments, rupture sources, rupture scenarios, and fault rupture models are determined using the terminology given in the Working Group of California Earthquake Probabilities (WGCEP-2003) report and multi-segment rupture scenarios are considered in a systematic manner. Events in the seismological database are attributed to the rupture systems and the logic tree weights for the rupture scenarios are determined by comparing the accumulated seismic moment due to the geological constraints (rupture dimensions and slip rate) with the seismic-moment release due to associated seismicity. In contrast to the previous efforts, the PSHA inputs (e.g., coordinates of the fault segments, logic tree branches and corresponding weights) are properly documented; therefore, the SSC model presented here can be directly implemented in the future site-specific PSHA studies in Istanbul.

\section{Fault segmentation models, rupture systems, and partitioning of slip rates}

The SSC model consists of one background source (defined in Sect. 5) and four distinct (non-overlapping) rupture systems that are defined by considering the rupture zones of previous large-magnitude earthquakes documented by Parsons (2004) on the northern strand of the NAFZ. We note that all subsegments in the defined rupture systems except for northern and southern Çınarcık segments are assumed to be near vertical with right-lateral slip as suggested by geological, seismological, and GPS data. The segmentation and the slip-rate partitioning models are not yet well established enough for the fault segments south of the Marmara Sea; therefore, these segments are not modeled as planar seismic sources in this SSC model.

\subsection{Izmit and Düzce rupture systems}

Location, geometry, and slip distribution of the rupture zones of the 1999 Kocaeli and Düzce earthquakes have been studied extensively after these events (e.g., Barka et al., 2002; Langridge et al., 2002; Akyüz et al., 2002). The surface rupture of the 1999 Kocaeli earthquake extended for almost $165 \mathrm{~km}$ and four distinct segments were ruptured (Hersek segment, Gölcük-Karamürsel-Izmit segment, Sapanca-Akyazı segment, and Karadere segment as given in Barka et al., 2002). The co-seismic fault was terminated at the western end of the rupture, very near to the eastern side of the Marmara Sea (Ergintav et al., 2014). The northern strand of the NAFZ that delimits the boundary between the Marmara Sea and Çınarcık Block did not rupture during the 1999 Kocaeli earthquake (Çınarcık segment in Fig. 1a). Mert et al. (2016) argued that the northern strand of the NAFZ 
is observed as a single continuous fault strand along Izmit Bay and at its entrance to the sea southeast of Istanbul. We included the northern Çınarcik segment (segment 3 ) in the Izmit rupture system because it is the western extension of the Hersek-Gölcük segment that was developed in response to the bending of the main strand of the NAFZ towards NW. This bending results in a releasing bend and a slip redistribution as dextral motion parallel to the main strand and normal motion perpendicular to the Çınarcık segments (Fig. 1d). As seen in Fig. 1e, the vertical throw of the northern Çinarcik segment is almost twice of the throw of the southern Çınarc1k segment, which is the conjugate fault of the northern Ç1narcık segment. The dip of the northern Çınarcık segment is assumed to be $70^{\circ} \mathrm{SW}$ as suggested by Laigle et al. (2008), while the dip of the southern Çınarcik segment is assumed to be $60^{\circ} \mathrm{NW}$. The Izmit rupture system proposed here consists of five (Hersek-Gölcük, Izmit, Sapanca-Akyazı, Karadare and northern Çınarcık) subsegments.

The Düzce earthquake produced a $40 \mathrm{~km}$ long surface rupture zone; however, there is a $4 \mathrm{~km}$ releasing step-over around Eften Lake (Akyüz et al., 2002). Therefore, a two-segment model (segments D1 and D2) is established for the rupture zone of the Düzce earthquake (Fig. 1a). The segments and segment lengths for the Izmit and Düzce rupture systems are given in Table 1. In 1999 earthquakes, these two rupture systems (Kocaeli and Düzce) were ruptured in two different episodes. A possible explanation for the separate ruptures in different episodes would be the development of the restraining bend along the Karadere segment, which probably locked up the eastern termination of Izmit rupture. Harris et al. (2002) proposed that the rupture of 1999 İzmit earthquake was stopped by a step-over at its eastern end (Mignan et al., 2015). In this study, we assumed the same rupture pattern of 1999 earthquakes and do not include a rupture scenario that combines these two rupture systems in the rupture forecast.

\subsection{Ganos/Saros rupture system}

The ENE-WSW-trending Ganos Fault is the fault segment at the westernmost section of the NAFZ that generated the 9 August 1912 Mürefte (Ganos) earthquake. Magnitudes of this earthquake were estimated from historical catalogs and field observations as $M_{\mathrm{S}}=7.3 \pm 0.3$ (by Ambraseys and Jackson, 2000) and $M_{\mathrm{w}}=7.4$ (by Altunel et al., 2004), respectively (Aksoy et al., 2010). A second large event occurred on 13 September $1912\left(M_{\mathrm{S}}=6.8 \pm 0.35\right.$ and the estimated seismic moment was $2.19 \times 10^{19} \mathrm{Nm}$ as given in Ambraseys and Jackson, 2000). Ambraseys and Jackson (2000) suggested a $37 \mathrm{~km}$ long co-seismic rupture for this large second shock. Aksoy et al. (2010) used the duration of the recorded waveforms to estimate the rupture lengths of 1912 events: assuming the rupture width is $15-20 \mathrm{~km}$, estimated values were $130 \pm 15 \mathrm{~km}$ and $110 \pm 30 \mathrm{~km}$ for the 9 August and 13 September events, respectively. According to Aksoy et al. (2010), co-seismic surface ruptures were visible along the $45 \mathrm{~km}$ onshore section of this segment. Supporting the estimations based on waveforms using aerial photographs, satellite imagery, digital elevation models, bathymetry, and field measurements, Aksoy et al. (2010) proposed $120 \pm 30 \mathrm{~km}$ long fault rupture for the 9 August 1912 event. Murru et al. (2016) defined two segments covering the $120 \pm 30 \mathrm{~km}$ long fault rupture of the 1912 Ganos earthquake: a $74 \mathrm{~km}$ long segment that includes the onshore section and a $46 \mathrm{~km}$ long offshore segment (segments 6 and 7 in Fig. 1a). The maximum seismogenic depth of these segments was assumed to be $15 \mathrm{~km}$ on the basis of the locking depth suggested by mechanical best fit modeling of GPS data (Flerit et al., 2003) and by the depth extent of instrumental seismicity (Gürbüz et al., 2000; Özalaybey et al., 2002; Örgülü and Aktar, 2001; Pınar et al., 2003). A similar segmentation model is adopted in this study by implementing minor changes in the subsegment lengths as shown in Table 1.

\subsection{Central Marmara rupture system}

The northern strand of the NAFZ forms a major transtensional NW-SE right bend under the Sea of Marmara at the Çınarcık trough (Murru et al., 2016). The fault trace follows the northern margin of the Marmara Sea and connects the complex central Marmara and Tekirdağ pull-apart basins, before merging into the NE-SW-striking Ganos Fault on land (Wong et al., 1995; Okay et al., 1999; Armijo et al., 2002; Le Pichon et al., 2001; Yaltirak, 2002; McNeill et al., 2004; Murru et al., 2016). Building the segmentation model for the offshore segments of the NAFZ (also known as the Central Marmara Fault, CMF) is especially difficult, because the fault traces are not directly observable (Aksu et al., 2000; Imren et al., 2001; Le Pichon et al., 2001; Armijo et al., 2002, 2005; Pondard et al., 2007). Murru et al. (2016) noted that the segments under Marmara Sea are bounded by geometric fault complexities and discontinuities (e.g., jogs and fault bends) that can act as barriers to rupture propagation (Segall and Pollard, 1980; Barka and Kadinsky-Cade, 1988; Wesnousky, 1988; Lettis et al., 2002; An, 1997) and proposed two separate segments for CMF. We adopted the fault geometry and the segments proposed by Murru et al. (2016) to build the two-segment central Marmara rupture system (see Fig. 1a for details). As mentioned by Murru et al. (2016), this model is consistent with the segmentation model proposed by Armijo et al. (2002) and in good agreement with the observed Marmara Sea basin morphology and geology (Flerit et al., 2003; Muller and Aydin, 2005; Carton et al., 2007; Pondard et al., 2007; Şengör et al., 2014). 
Table 1. The fault segments and rupture systems included in the SSC model. References given in the last column are (1) Flerit et al. (2004), (2) Murru et al. (2016), (3) Ergintav et al. (2014), (4) Ayhan et al. (2001), (5) Hergert et al. (2011). Weights associated with the mean, upper bound and lower bound are $0.5,0.25$, and 0.25 , respectively.

\begin{tabular}{|c|c|c|c|c|c|c|}
\hline Rupture system & $\begin{array}{l}\text { Segment } \\
\text { no. }\end{array}$ & Segment name & $\begin{array}{l}\text { Length } \\
(\mathrm{km})\end{array}$ & $\begin{array}{l}\text { Width } \\
(\mathrm{km})\end{array}$ & $\begin{array}{l}\text { Slip rate and associated } \\
\text { uncertainty }\left(\mathrm{mm} \mathrm{yr}^{-1}\right)\end{array}$ & $\begin{array}{l}\text { Reference for } \\
\text { the slip rate } \\
\text { estimation }\end{array}$ \\
\hline Izmit & 3 & North Çınarcık & 34.6 & 18 & $17 \pm 2(6 \pm 2$ extension $)$ & 1, 2, 3, Fig. 1 \\
\hline Izmit & 2_1 & Hersek-Gölcük & 51.6 & 18 & $19 \pm 2$ & $1,2,3$ \\
\hline Izmit & $2 \_2$ & İzmit & 30.2 & 18 & $19 \pm 2$ & $1,2,3$ \\
\hline Izmit & $2 \_3$ & Sapanca-Akyazı & 39.1 & 18 & $19 \pm 2$ & $1,2,3$ \\
\hline Izmit & 1 & Karadere & 24.7 & 18 & $10 \pm 2$ & 1,4 \\
\hline Düzce & D1 & Düzce_1 & 10.5 & 25 & $10 \pm 2$ & 1,4 \\
\hline Düzce & $\mathrm{D} 2$ & Düzce_2 & 41 & 25 & $10 \pm 2$ & 1,4 \\
\hline Ganos/Saros & 6 & Ganos & 84 & 15 & $19 \pm 1$ & $1,3,4,5$ \\
\hline Ganos/Saros & 7 & Saros & 53 & 15 & $19 \pm 1$ & $1,3,4,5$ \\
\hline Central Marmara & 4 & Central Marmara & 80 & 15 & $19 \pm 2$ & 1,2 \\
\hline Central Marmara & 5 & Western Marmara & 49 & 15 & $19 \pm 2$ & 1,2 \\
\hline Çınarcık & 8 & Southern Çınarcık & 39 & 18 & $(3 \pm 2$ extension $)$ & 2, Fig. 1 \\
\hline
\end{tabular}

\subsection{Annual slip rates}

Past studies based on GPS measurements (McClusky et al., 2000; Meade et al., 2002; Armijo et al., 2002; Reilinger et al., 2006; Hergert and Heidbach, 2010; Ergintav et al., 2014) suggest a $22 \pm 3 \mathrm{~mm} \mathrm{yr}^{-1}$ dextral motion along the major block-bounding structures of the NAFZ, with more than $80 \%$ being accommodated along the northern branch. On this branch, the segments that formed the western and central parts of the Izmit rupture system (segments 3, 2_1, $2 \_2$ and 2_3 in Fig. 1a) share the total slip rate with GeyveIznik Fault. The slip-rate participation among the northern strand of the NAFZ and the Geyve-Iznik Fault was given as 16 and $9 \mathrm{~mm} \mathrm{yr}^{-1}$ in Stein et al. (1997). However, Murru et al. (2016) have adopted the annual slip rate of $20 \pm 2 \mathrm{~mm} \mathrm{yr}^{-1}$ for the northern strand based on the proposals of Flerit et al. (2003) and Ergintav et al. (2014). Similarly, we achieved a better fit with the associated seismicity of Izmit rupture system by assigning a $19 \pm 2 \mathrm{~mm} \mathrm{yr}^{-1}$ annual slip rate to the northern strand of the NAFZ (please refer to Sect. 4 for further details). Similarly, the total slip rate is distributed over the eastern segment of the NAFZ southern strand (segment 1 in Fig. 1a) and the segments of Düzce rupture system (D1 and D2). Ayhan et al. (2001) suggested that up to $10 \mathrm{~mm} \mathrm{yr}^{-1}$ of the motion is accommodated on the DüzceKaradere strand of the NAF. We also utilized the same annual slip rate of $10 \pm 2 \mathrm{mmyr}^{-1}$ for Düzce_1, Düzce_2 and Karadere segments without any modifications (Table 1).

The mean slip rates adopted for central and western Marmara subsegments $\left(19 \mathrm{~mm} \mathrm{yr}^{-1}\right)$ are consistent with the neighboring subsegments of the Izmit and Ganos/Saros rupture systems. Ergintav et al. (2014) noted that the Prince Island Fault (PIF) (segment 4) is actively accumulating strain and has not experienced a large event since 1766, making it the most likely segment to generate a $M>7$ earthquake. The slip-rate estimate given in Ergintav et al. (2014) for the PIF and Çınarcık Basin is $15 \pm 2 \mathrm{~mm} \mathrm{yr}^{-1}$. Murru et al. (2016) distributed the annual slip rate of $17 \mathrm{~mm} \mathrm{yr}^{-1}$ among two parallel branches in this zone: $14 \pm 2 \mathrm{~mm} \mathrm{yr}^{-1}$ for the Çınarcık segment and $3 \pm 1 \mathrm{~mm} \mathrm{yr}^{-1}$ for the southern Çınarcık segment based on the recent works of Ergintav et al. (2014) and Hergert and Heidbach (2010). Therefore, the slip-rate value that we have used on the horizontal plane $\left(17 \mathrm{~mm} \mathrm{yr}^{-1}\right)$ is identical to these recent estimates (Fig. 1d). In our analysis, the $6 \pm 2 \mathrm{~mm} \mathrm{yr}^{-1}$ extension is assigned to the northern Çınarc1k segment, while $3 \pm 2 \mathrm{~mm} \mathrm{yr}^{-1}$ is assigned to the southern Çınarcık segment. Since the northern Çınarcık segment was ruptured during the 17 August 1999 earthquake, we assumed that all the strike-slip motion was taken up by the northern Çınarcik segment; therefore, the entire $17 \mathrm{~mm} \mathrm{yr}^{-1}$ dextral motion is assigned to the northern Çinarcık segment. The slip rate given for the Central Marmara Fault by Ergintav et al. (2014) $\left(2 \mathrm{~mm} \mathrm{yr}^{-1}\right)$ is unusually low compared to the previous estimates and may be suffering from the sparsity of the network and GPS coverage on the northern shores of Marmara Sea as mentioned by the authors. For this rupture system, the annual slip rate we adopted $\left(19 \pm 2 \mathrm{~mm} \mathrm{yr}^{-1}\right)$ is in good agreement with the value given in Murru et al. (2016) $\left(18 \pm 2 \mathrm{~mm} \mathrm{yr}^{-1}\right)$ and with the seismicity rates based on the instrumental earthquake catalog (Fig. 4b).

The slip rate given in the SSC model of Murru et al. (2016) is directly adopted for the Ganos subsegment, whereas the slip rate partitioned between the North Saros and South Saros subsegments in Murru et al. (2016) is concentrated over the Saros subsegment (Table 1). This is because the southern segment is developed in response to transtension exerted by the curvilinear trace of the northern segment (Okay et al., 2004), a mechanism somewhat similar to the northern and southern 


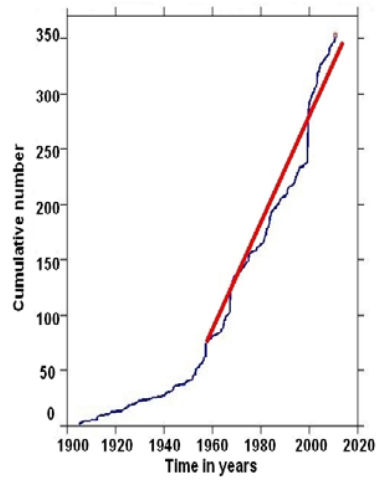

(a)

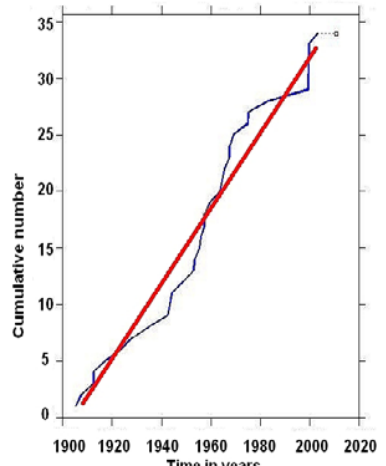

(d)

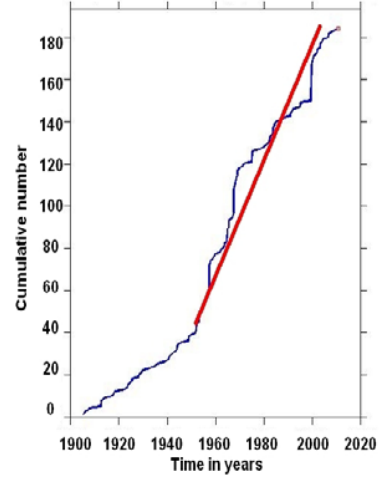

(b)

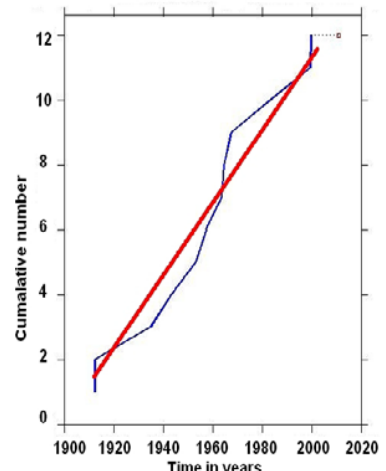

(e)

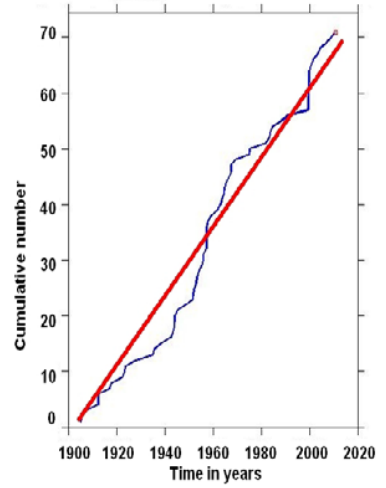

(c)

Figure 2. The catalog completeness analysis for the instrumental earthquake catalog showing the cumulative number of events for (a) $M_{\mathrm{W}} \geq$ 4.0 , (b) $M_{\mathrm{W}} \geq 4.5$, (c) $M_{\mathrm{W}} \geq 5.0$, (d) $M_{\mathrm{W}} \geq 5.5$, and (e) $M_{\mathrm{W}} \geq 6.0$.

Çınarcik segments proposed above. The slip rate assigned to the Ganos and Saros subsegments is consistent with the recent GPS velocity profiles given in Hergert and Heidbach (2010) and Ergintav et al. (2014). Table 1 summarizes the references for the utilized annual slip rates for each segment and the uncertainty related to the slip rate included in the logic tree.

\section{Instrumental earthquake catalog and activity rates of earthquakes}

The catalog of earthquakes documenting the available knowledge of past seismicity within the site region is a key component of the seismic source characterization for the hazard analysis. A very detailed review of the historical earthquakes and their rupture zones around the Marmara Sea region was documented by Parsons (2004). These earthquakes and the extension of their rupture zones are directly utilized in this study to define the subsegments, rupture systems, and to calculate the mean characteristic magnitude values. The Integrated and Homogeneous Turkish Earthquake Catalog published by KOERI (Kalafat et al., 2011), including the events with $M_{\mathrm{w}}>4$ that occurred between 1900 and 2010, is employed to represent the instrumental seismicity in the region. It is notable that areal source zones (or polygons) are not utilized in the SSC model to estimate the activity rates; therefore, the maximum magnitude estimates and the PSHA results are not solely dependent on the collected catalog. The mainshock-aftershock classification of the catalog (declustering) is performed and the aftershocks are removed from the data set using the Reasenberg (1985) methodology in the ZMAP software package (Wiemer, 2001) with minimum and maximum look-ahead times of 1 and 10 days and an event crack radius of $10 \mathrm{~km}$.

Catalog completeness analysis for different magnitude ranges is performed in order to achieve the catalog completeness levels used in calculating the magnitude recurrence parameters. Cumulative rates of earthquakes larger than specific magnitude levels are plotted against years in order to examine the completeness of the catalog as shown in Fig. 2. For different cut-off magnitudes, the breaking points for the linear trends in the cumulative rate of events are examined and a significant breaking point is observed to be at 52 years from the end of the catalog for magnitudes smaller than 4.5 and 5.0. Therefore, the catalog was assumed to be complete for 52 years for $4.0 \leq M_{\mathrm{w}} \leq 4.5$ and $4.5 \leq M_{\mathrm{w}} \leq 5.0$ earthquakes, respectively. Although the larger magnitude plots in Fig. 2 suffer from a lack of data due to the truncation of the catalog, the catalog is assumed to be complete for the greater 
Table 2. $b$ values estimated using different methods and corresponding weights in the logic tree.

\begin{tabular}{|c|c|c|c|c|c|c|}
\hline \multirow[t]{2}{*}{ Source zone } & \multicolumn{2}{|c|}{$\begin{array}{l}\text { Maximum likelihood } \\
\text { estimation by ZMAP } \\
\text { (zone specific) }\end{array}$} & \multicolumn{2}{|c|}{$\begin{array}{l}\text { Maximum likelihood } \\
\text { estimation by } \\
\text { Weichert (1980) } \\
\text { (zone specific) }\end{array}$} & \multicolumn{2}{|c|}{ Regional value } \\
\hline & $b$ value & weight & $b$ value & weight & $b$ value & weight \\
\hline Düzce rupture system & 0.68 & 0.3 & 0.72 & 0.3 & 0.76 & 0.4 \\
\hline Izmit rupture system & 0.68 & 0.3 & 0.72 & 0.3 & 0.76 & 0.4 \\
\hline Central Marmara rupture system & 0.74 & 0.3 & 0.78 & 0.3 & 0.76 & 0.4 \\
\hline \multirow[t]{2}{*}{ Ganos/Saros rupture system } & 0.74 & 0.3 & 0.78 & 0.3 & 0.76 & 0.4 \\
\hline & \multicolumn{2}{|c|}{$\begin{array}{l}\text { Maximum likelihood } \\
\text { estimation by } \\
\text { Weichert }(1980) \\
(\text { Mean }-2 \sigma)\end{array}$} & \multicolumn{2}{|c|}{$\begin{array}{l}\text { Maximum likelihood } \\
\text { estimation by } \\
\text { Weichert (1980) } \\
\text { (Mean) }\end{array}$} & \multicolumn{2}{|c|}{$\begin{array}{l}\text { Maximum likelihood } \\
\text { estimation by } \\
\text { Weichert }(1980) \\
(\text { Mean }+2 \sigma)\end{array}$} \\
\hline \multirow[t]{2}{*}{ Background zone } & $b$ value & weight & $b$ value & weight & $b$ value & weight \\
\hline & 0.714 & 0.20 & 0.81 & 0.60 & 0.906 & 0.20 \\
\hline
\end{tabular}

magnitudes for the whole time span (110 years). The catalog completeness intervals used in Şeşetyan et al. (2016) and in this study for $4.7<M<5.7$ earthquakes are consistent even if the compiled catalogs are different.

The magnitude-frequency relationship developed for each rupture system and the background zone is explained in the next section. Only one of the magnitude-frequency relationship parameters, the slope of the cumulative rate of events (as known as the $b$ value), is calculated based on the compiled catalog. We delineated three different zones for estimating the $b$ value considering the temporal and spatial variability of this parameter as shown in Fig. 1c. Zone 1 includes the Ganos/Saros and central Marmara rupture systems, Zone 2 covers the Izmit and Düzce rupture systems, and Zone 3 is a larger area that includes both Zone 1 and Zone 2. For each zone, the $b$ value is estimated using the maximum likelihood method provided in the ZMAP software package. Figure 3a$\mathrm{c}$ shows the completeness magnitudes and the $b$ values for zones 1, 2, and 3. Analysis results show that the $b$ value varies between 0.68 and 0.74 for different rupture systems given in the previous section, whereas the $b$ value for the large area covering the whole system is equal to 0.76 .

Additionally, the $b$ values for each zone are estimated using the modified maximum likelihood method (Weichert, 1980) that takes into account the completeness of the catalog for different magnitude bins. The $b$ values calculated using the Weichert (1980) method are approximately 5\% higher than the maximum likelihood estimations of ZMAP for zones 1 and 2, but for the larger zone (Zone 3), estimated $b$ values are almost the same in both methods (Table 2). To acknowledge the uncertainty in the $b$ value estimations, $30 \%$ weight is assigned to the zone-specific $b$ value calculated by ZMAP and the zone-specific $b$ value calculated using Weichert (1980) method each, and $40 \%$ weight is given to the regional $b$ value since the number of data in this zone are larger and the estimated $b$ value is statistically more stable. Finally, the $b$ value for the background zone (limits shown in Fig. 5) is calculated as 0.81 by removing the earthquakes within the buffer zones. Uncertainty in the $b$ value of the background zone is determined using the method proposed by Shi and Bolt (1982) and included in the logic tree (Table 2).

Estimated $b$ values are relatively small when compared to the $b$ values estimated for large areas $(b \approx 1)$; however, our findings are consistent with the current literature. Şeşetyan et al. (2016) provided a thorough analysis of the $b$ value for the Turkish territory and proposed that $b=0.77$ for the central Marmara region and $b=0.67$ for the North Anatolian fault zone (Fig. 15 of Şeşetyan et al., 2016). The small differences in the $b$ values proposed by Şeşetyan et al. (2016) and the $b$ values estimated in this study are due to the geometry of the selected zones and the differences in the compiled catalogs. The $b$ value used by Moschetti et al. (2015) for the western United States $(b=0.8)$ is not very different to our estimates.

\section{Magnitude recurrence models - seismic moments}

Seismic sources can generate varied sizes of earthquakes and magnitude distribution models describe the relative rates of these small, moderate and large earthquakes. The basic and the most common magnitude frequency distribution (MFD) is the exponential model proposed by Gutenberg and Richter (1944) (G-R). Since there is a maximum magnitude that the source can produce and a minimum magnitude for engineering interest, the $\mathrm{G}-\mathrm{R}$ distribution is usually truncated at both ends and renormalized so that it integrates 


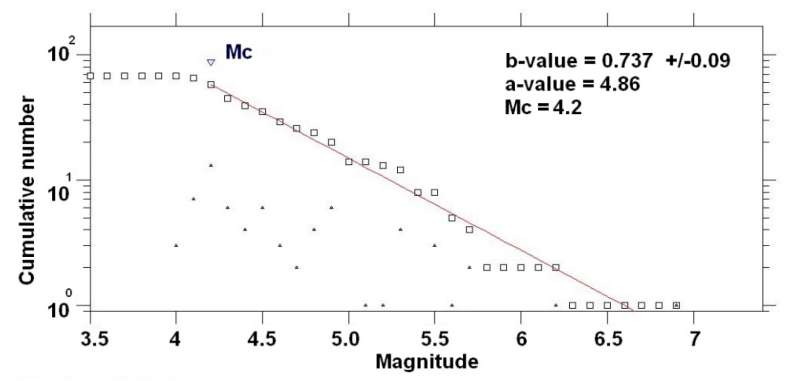

(a)

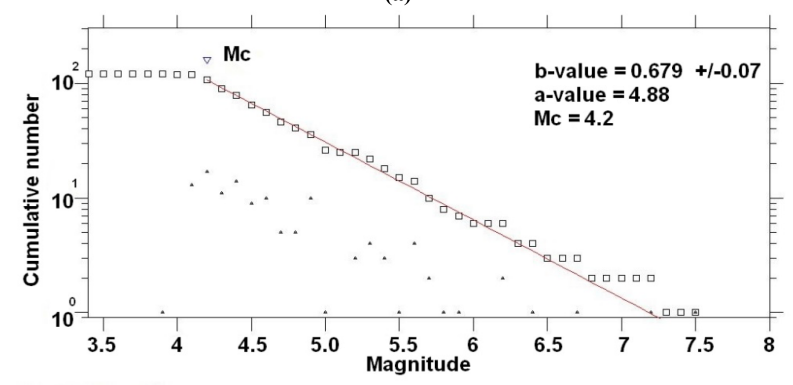

(b)

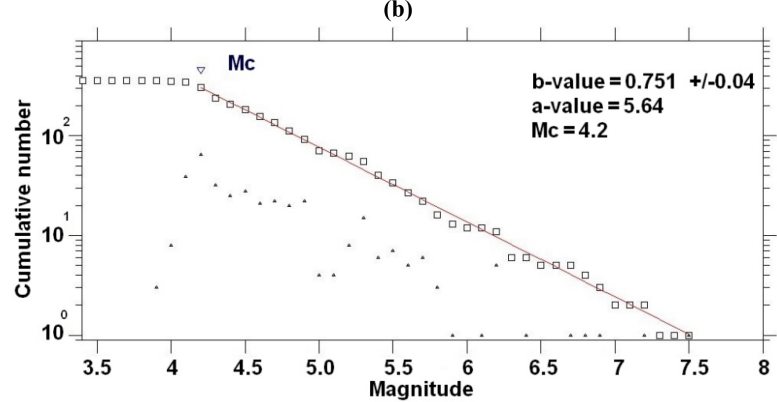

(c)

Figure 3. Estimated magnitude recurrence parameters for (a) Zone 1, (b) Zone 2, and (c) Zone 3.

to unity. The truncated exponential MFD (Cosentino et al., 1977) is given in Eq. (1):

$f_{m}^{\mathrm{TE}}(M)=\frac{\beta \exp \left(-\beta\left(M-M_{\min }\right)\right)}{1-\exp \left(-\beta\left(M_{\max }-M_{\min }\right)\right)}$,

where $\beta=\ln (10) \times b$ value, $M_{\min }$ is the minimum magnitude, and $M_{\max }$ is the maximum magnitude. Youngs and Coppersmith (1985) proposed that the truncated exponential distribution is suitable for large regions or regions with multiple faults, but in most cases it does not work well for individual faults. Instead, individual faults may tend to rupture at what have been termed "characteristic" size events and the alternative magnitude distribution for this case is the characteristic model proposed by Schwartz and Coppersmith (1984). In characteristic MFD, once a fault begins to rupture in large earthquakes, it tends to rupture the entire fault segment and produce similar size earthquakes due to the geometry of the fault. It is notable that the characteristic model does not consider the small-to-moderate magnitude earth- quakes on a fault. A third model was proposed by Youngs and Coppersmith in 1985 that combines the truncated exponential and characteristic magnitude distributions as shown in Eqs. (2) and (3):

$f_{m}^{\mathrm{YC}}(M)=$
$\left\{\begin{array}{c}\frac{1}{1+c_{2}} \times \frac{\beta \exp \left(-\beta\left(\bar{M}_{\text {char }}-M_{\min }-1.25\right)\right)}{1-\exp \left(-\beta\left(\bar{M}_{\text {char }}-M_{\min }-0.25\right)\right)} \\ \text { for } \bar{M}_{\text {char }}-0.25<M \leq \bar{M}_{\text {char }}+0.25 \\ \frac{1}{1+c_{2}} \times \frac{\beta \exp \left(-\beta\left(M-M_{\min }\right)\right)}{1-\exp \left(-\beta\left(\bar{M}_{\text {char }}-M_{\min }-0.25\right)\right)} \\ \text { for } M_{\text {min }}<M \leq \bar{M}_{\text {char }}-0.25 \\ , \quad\end{array}\right.$

where

$c_{2}=\frac{0.5 \beta \exp \left(-\beta\left(\bar{M}_{\mathrm{char}}-M_{\min }-1.25\right)\right)}{1-\exp \left(-\beta\left(M_{\mathrm{char}}-M_{\min }-0.25\right)\right)}$, 
(a)

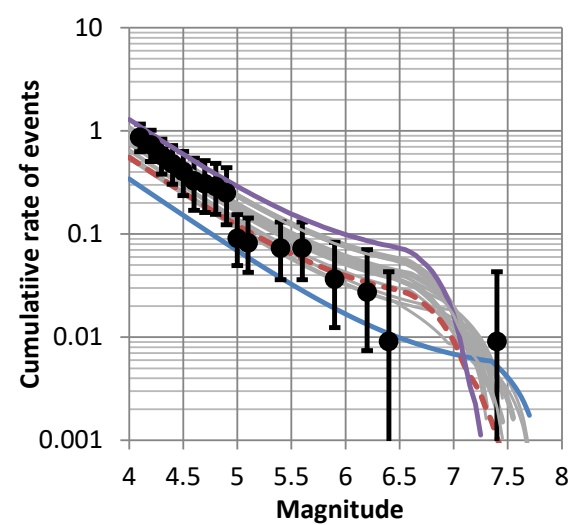

(c)

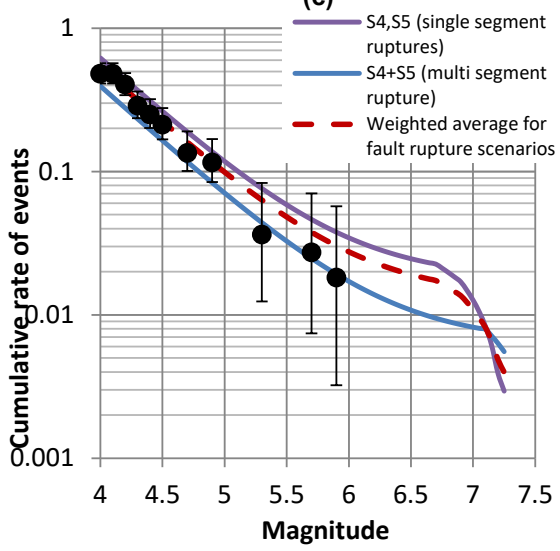

(b)

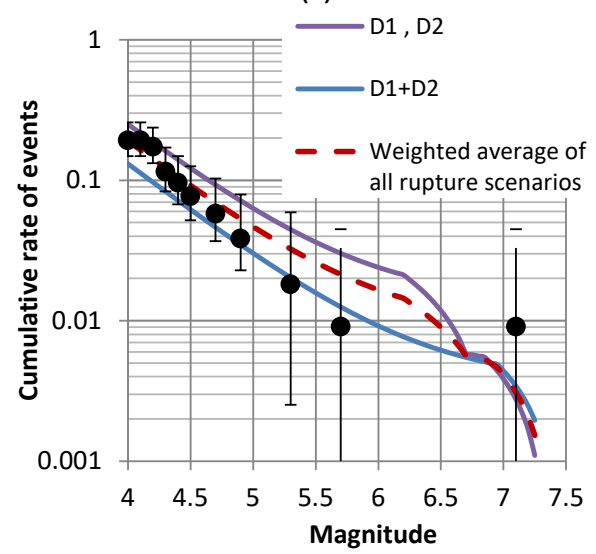

(d)

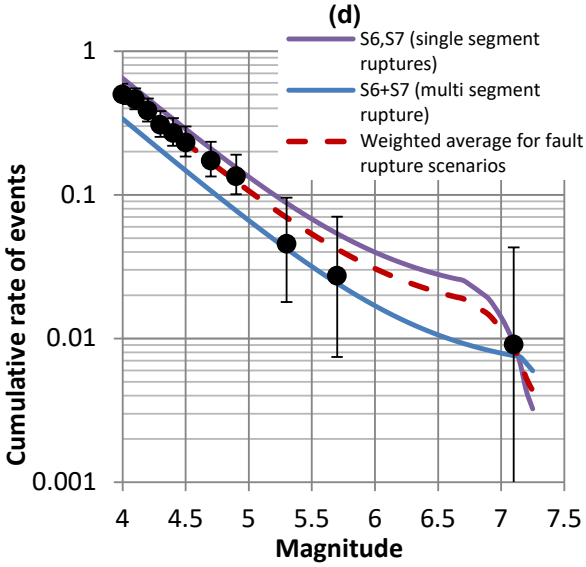

Figure 4. Cumulative rates of earthquakes for the magnitude recurrence model and associated events (moment-balancing graphs) for (a) Izmit, (b) Düzce, (c) central Marmara, and (d) Ganos/Saros rupture systems. Black points are the earthquakes associated with the rupture system; purple and blue lines show the single-segment and multi-segment ruptures; the red broken line is the weighted average of the magnitude recurrence model. In these graphs, the median values of the slip rates and $M_{\max }$ and zone-specific $b$ values are utilized.

and $M_{\text {char }}$ is the characteristic earthquake magnitude. Coupling the truncated exponential MFD with seismic sources defined by planar fault geometries results in unrealistically high rates for small-to-moderate magnitude events (Hecker et al., 2013), especially in the close vicinity of the NAFZ (Gülerce and Vakilinezhad, 2015). Therefore, the composite MFD proposed by Youngs and Coppersmith (1985) is utilized to represent the relative rates of small, moderate and large-magnitude earthquakes generated by rupture sources defined in this study.

The rupture systems presented in Sect. 2 include more than one subsegment. We adopted the terminology of WGCEP (2003) and defined the rupture source as a fault subsegment or a combination of multiple adjacent fault subsegments that may rupture and produce an earthquake in the future. For Düzce, central Marmara, and Ganos/Saros rupture systems with two subsegments (as A and B), three different rupture sources can be defined: single segment sources (A and B) and a two-subsegment source $(\mathrm{A}+\mathrm{B})$. Any possible combination of rupture sources that describes the complete rupture of the system is defined as the rupture scenario. Two rupture scenarios for these rupture systems are (1) rupture of the two subsegments individually and (2) rupture of the two subsegments together. The rupture model includes the weighted combination of rupture scenarios of the rupture system. Five segments defined for Izmit rupture systems form a rupture model with 15 rupture sources and 16 rupture scenarios (Table 5). The minimum magnitude $\left(M_{\min }\right)$ is set to $M_{\mathrm{w}}=4.0$ for all rupture sources considering the completeness magnitude. Mean characteristic magnitudes $\left(M_{\text {char }}\right)$ for each rupture source are calculated using the relationships proposed by Wells and Coppersmith (1994) and Hanks and Bakun (2014). The $M_{\text {char values calculated using both equations are quite }}$ close to each other and the absolute value of the difference is smaller than 0.13 in magnitude units (Table 6). To grasp the epistemic uncertainty, the average of the $M_{\text {char }}$ value from both methods are utilized in the center of the logic tree with $50 \%$ weight and both the $M_{\text {char }}-0.15$ and $M_{\text {char }}+0.15$ values are included by assigning $25 \%$ weight. The upper bound for the magnitude PDF $\left(M_{\max }\right)$ is determined by adding 0.25 
Table 3. Aleatory variability for style of faulting in the background zone.

\begin{tabular}{lllll}
\hline \multirow{2}{*}{ Weights } & \multicolumn{4}{c}{ Style of faulting } \\
& Normal & Strike slip & Reverse & Normal-oblique \\
\hline 150 km radius background zone & 0.20 & 0.75 & 0.05 \\
All segments except Çınarcık Fault & - & 1.00 & - & \multirow{2}{*}{1.0} \\
Northern and southern Çınarcık segments & - & - & - & 0 \\
\hline
\end{tabular}

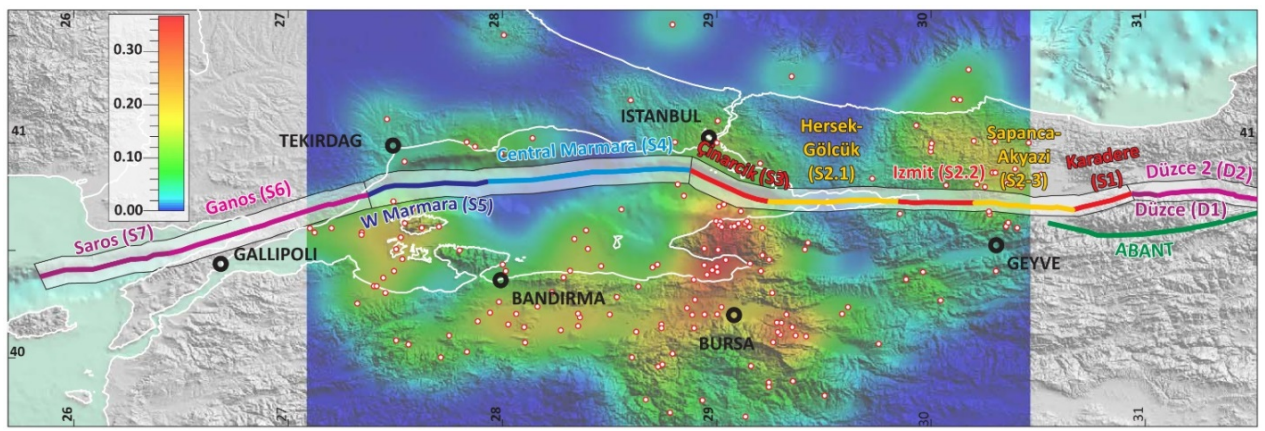

Figure 5. Spatial distribution of the activity rates in the smoothed seismicity source. Red circles are the earthquakes used in the analysis.

magnitude units to $M_{\text {char }}$ for each source in each logic tree branch (Table 6).

MFD only represents the relative rate of different magnitude earthquakes. In order to calculate the absolute rate of events, the activity rate $N\left(M_{\min }\right)$ defined as the rate of earthquakes above the minimum magnitude should be used. For areal sources, $N\left(M_{\min }\right)$ may be calculated by using the seismicity within the defined area. For planar fault sources, the activity rate is defined by the balance between the accumulated and released seismic moments as shown in Eq. (4). The accumulated seismic moment is a function of the annual slip rate $(S)$ in $\mathrm{cm} \mathrm{yr}^{-1}$, area of the fault $\left(A\right.$ in $\left.\mathrm{cm}^{2}\right)$, and the shear modulus of the crust $\left(\mu=30 \times 10^{12} \mathrm{dyne}^{-2}\right.$, Brodsky et al., 2000; Field et al., 2009). The $S$ for the rupture sources that includes more than one segment with different $S$ values are calculated using the weighted average of annual slip rates (weights are determined based on the area of the segment as shown in Eq. 5).

$$
\begin{aligned}
& N\left(M_{\mathrm{min}}\right)=\frac{\mu A S}{\int_{M_{\min }}^{M_{\max }} f_{m}\left(M_{\mathrm{w}}\right) 10^{1.5 M_{\mathrm{w}}+16.05} \mathrm{~d} M} \\
& S_{\text {source }}=\frac{\sum_{\text {all segments for the source }} S_{\text {segment }} \times A_{\text {segment }}}{\sum_{\text {all segments for the source }} A_{\text {segment }}}
\end{aligned}
$$

Ultimately the MFD and the activity rate are used to calculate the magnitude recurrence relation, $N(M)$, as shown in Eq. (6).

$N(M)=N\left(M_{\min }\right) \int_{M_{\min }}^{M_{\max }} f_{m}\left(M_{\mathrm{w}}\right) \mathrm{d} M$
The magnitude recurrence relation given in Eq. (6) and the accuracy of the model parameters such as the $b$ value or $M_{\max }$ shall be tested by the relative frequency of the seismicity associated with the source in the moment-balanced PSHA procedure. Therefore, a weight is assigned to each rupture scenario and the cumulative rates of events attributed to that particular rupture system are plotted along with the weighted average of the rupture scenarios to calibrate the assigned weights and to evaluate the balance of the accumulated and released seismic moment. The moment-balancing graphs for Izmit, Düzce, central Marmara, and Ganos/Saros rupture systems are provided in Fig. 4 and used to compare the modeled seismicity rate with the instrumental earthquake catalog. In these plots, the black dots stand for the cumulative annual rates of earthquakes and the error bars represent the uncertainty introduced by unequal periods of observation for different magnitudes (Weichert, 1980). In Fig. 4, the scenarios that are separated by plus signs in the legend are the scenarios with multiple rupture sources. When multiple segments rupture together, these scenarios are separated by a comma sign in the legend. For example, the "S4, S5" line in Fig. 4c represents the scenario where S4 and S5 subsegments are ruptured individually. This scenario brings in relatively higher rates for small-to-moderate earthquakes when compared to the $\mathrm{S} 4+\mathrm{S} 5$ scenario, which represents the rupture of these two segments together to produce a larger event.

The best fit between the cumulative annual rate of events and the weighted average of rupture scenarios (red dashed lines) is established by modifying the weights of the rupture scenarios by visual interpretation. To achieve a good fit, the seismic source modeler needs to understand the contribution of the magnitude recurrence model parameters to the 
Table 4. Aleatory variability in the rupture scenario weights.

\begin{tabular}{llll}
\hline Rupture system & Rupture type & Included subsegment no. & Weight \\
\hline \multirow{2}{*}{ Düzce rupture system } & Single segment ruptures & D1, D2 & 0.5 \\
\cline { 2 - 4 } & Two-segment ruptures & D1 + D2 & 0.5 \\
\hline Central Marmara rupture system & Single segment ruptures & $4+5$ & 0.6 \\
\cline { 2 - 4 } & Two-segment ruptures & $4+5$ & 0.4 \\
\hline Ganos/Saros rupture system & Single segment ruptures & $6+7$ & 0.6 \\
\cline { 2 - 4 } & Two-segment ruptures & $6+7$ & 0.4 \\
\hline Izmit rupture system & & Table 5 & \\
\hline
\end{tabular}

Table 5. Rupture sources and rupture scenarios utilized for the Izmit rupture system ${ }^{\mathrm{a}}$.

\begin{tabular}{|c|c|c|c|c|c|c|c|c|c|c|c|c|c|c|c|c|c|}
\hline & 3 & $2 \_1$ & $2 \_2$ & $2 \_3$ & 1 & $\begin{array}{l}3+ \\
2 \_1\end{array}$ & $\begin{array}{l}2 \_1+ \\
2 \_2\end{array}$ & $\begin{array}{l}2 \_2+ \\
2 \_3\end{array}$ & $\begin{array}{l}2 \_3+ \\
1\end{array}$ & $\begin{array}{l}3+ \\
2 \_1+ \\
2 \_2\end{array}$ & $\begin{array}{l}2 \_1+ \\
2 \_2+ \\
2 \_3\end{array}$ & $\begin{array}{l}2 \_2+ \\
2 \_3+ \\
2 \_4\end{array}$ & $\begin{array}{l}3+ \\
2 \_1+ \\
2 \_2+ \\
2 \_3\end{array}$ & $\begin{array}{l}2 \_1+ \\
2 \_2+ \\
2 \_3+ \\
1\end{array}$ & $\begin{array}{l}3+ \\
2 \_1+ \\
2 \_2+ \\
2 \_3+ \\
1\end{array}$ & $\begin{array}{l}\text { Rupture } \\
\text { scenario }\end{array}$ & Weight \\
\hline $3,2 \_1,2 \_2,2 \_3,1$ & 1 & 1 & 1 & 1 & 1 & 0 & 0 & 0 & 0 & 0 & 0 & 0 & 0 & 0 & 0 & 1 & 0.20 \\
\hline $3+2 \_1,2 \_2,2 \_3,1$ & 0 & 0 & 1 & 1 & 1 & 1 & 0 & 0 & 0 & 0 & 0 & 0 & 0 & 0 & 0 & 2 & 0.07 \\
\hline $3,2 \_1+2 \_2,2 \_3,1$ & 1 & 0 & 0 & 1 & 1 & 0 & 1 & 0 & 0 & 0 & 0 & 0 & 0 & 0 & 0 & 3 & 0.07 \\
\hline $3,2 \_1,2 \_2+2 \_3,1$ & 1 & 1 & 0 & 0 & 1 & 0 & 0 & 1 & 0 & 0 & 0 & 0 & 0 & 0 & 0 & 4 & 0.07 \\
\hline $3,2 \_1,2 \_2,2 \_3+1$ & 1 & 1 & 1 & 0 & 0 & 0 & 0 & 0 & 1 & 0 & 0 & 0 & 0 & 0 & 0 & 5 & 0.07 \\
\hline $3+2 \_1+2 \_2,2 \_3,1$ & 0 & 0 & 0 & 1 & 1 & 0 & 0 & 0 & 0 & 1 & 0 & 0 & 0 & 0 & 0 & 6 & 0.05 \\
\hline $3,2 \_1+2 \_2+2 \_3,1$ & 1 & 0 & 0 & 0 & 1 & 0 & 0 & 0 & 0 & 0 & 1 & 0 & 0 & 0 & 0 & 7 & 0.05 \\
\hline $3,2 \_1,2 \_2+2 \_3+1$ & 1 & 1 & 0 & 0 & 0 & 0 & 0 & 0 & 0 & 0 & 0 & 1 & 0 & 0 & 0 & 8 & 0.05 \\
\hline $3+2 \_1+2 \_2+2 \_3,1$ & 0 & 0 & 0 & 0 & 1 & 0 & 0 & 0 & 0 & 0 & 0 & 0 & 1 & 0 & 0 & 9 & 0.05 \\
\hline $3,2 \_1+2 \_2+2 \_3+1$ & 1 & 0 & 0 & 0 & 0 & 0 & 0 & 0 & 0 & 0 & 0 & 0 & 0 & 1 & 0 & 10 & 0.03 \\
\hline $3+2 \_1,2 \_2+2 \_3,1$ & 0 & 0 & 0 & 0 & 1 & 1 & 0 & 1 & 0 & 0 & 0 & 0 & 0 & 0 & 0 & 11 & 0.03 \\
\hline $3,2 \_1+2 \_2,2 \_3+1$ & 1 & 0 & 0 & 0 & 0 & 0 & 1 & 0 & 1 & 0 & 0 & 0 & 0 & 0 & 0 & 12 & 0.03 \\
\hline $3+2 \_1+2 \_2,2 \_3+1$ & 0 & 0 & 0 & 0 & 0 & 0 & 0 & 0 & 1 & 1 & 0 & 0 & 0 & 0 & 0 & 13 & 0.03 \\
\hline $3+2 \_1,2 \_2+2 \_3+1$ & 0 & 0 & 0 & 0 & 0 & 1 & 0 & 0 & 0 & 0 & 0 & 1 & 0 & 0 & 0 & 14 & 0.03 \\
\hline $3+2 \_1,2 \_2,2 \_3+1$ & 0 & 0 & 1 & 0 & 0 & 1 & 0 & 0 & 1 & 0 & 0 & 0 & 0 & 0 & 0 & 15 & 0.03 \\
\hline $3+2 \_1+2 \_2+2 \_3+1$ & 0 & 0 & 0 & 0 & 0 & 0 & 0 & 0 & 0 & 0 & 0 & 0 & 0 & 0 & 1 & 16 & 0.14 \\
\hline Rupture source no. & 1 & 2 & 3 & 4 & 5 & 6 & 7 & 8 & 9 & 10 & 11 & 12 & 13 & 14 & 15 & & \\
\hline
\end{tabular}

${ }^{a}$ Note: rows show the rupture scenarios and the columns show the rupture sources. 1 and 0 in a cell indicate that the particular rupture source is included or excluded in the rupture scenario, respectively. Scenario weights are given in the last column. For subsegments 3,2_1, 2_2, 2_3, and 1, please refer to Fig. 1b.

red broken line in different magnitude ranges. For example, the $b$ value significantly affects the small magnitude portion of the curve, since the Youngs and Coppersmith (1985) magnitude PDF is used. Please remember that the $b$ value is calculated based on the same catalog but for a larger region. Defining a large number of subsegments for a rupture system also increases the cumulative rate of small magnitude events. The good fit in the small magnitude range of Fig. 4 shows that (i) the $b$ value calculated using the larger zone is compatible with the seismicity associated with the planar source, (ii) the utilized segmentation model is consistent with the relative rates of small-to-moderate and large events, and (iii) the annual slip rate is compatible with the seismicity over the fault. The large magnitude rates in Fig. 4 are poorly constrained since the catalog used herein only covers 110 years and that time span is obviously shorter than the recurrence rate for the large-magnitude event. Hecker et al. (2013) explained that by "rates of large-magnitude earthquakes on individual faults are so low that the historical record is not long enough to test this part of the distribution" and suggested using the "inter-event variability of surface-rupturing displacement at a point as derived from geologic data sets" to test the upper part of the earthquake-magnitude distribution. In each moment-balancing plot, relatively higher weights are assigned to the rupture scenarios that combine the individual (single-segment) rupture sources based on the assumption (and modeler's preference) that single-segment ruptures are more likely than multiple-segment ruptures. The weights assigned to each rupture scenario are given in Table 4. 
Table 6. Logic tree representing epistemic uncertainty in maximum magnitudes. Weights for $M_{\max } 1, M_{\max } 2$, and $M_{\max } 3$ are $0.25,0.5$, and 0.25, respectively (WC94: Wells and Coppersmith, 1994, and HB14: Hanks and Bakun, 2014, magnitude-rupture-area relation).

\begin{tabular}{|c|c|c|c|c|c|c|c|c|}
\hline Rupture system & Rupture source & $\begin{array}{l}\text { Source } \\
\text { width } \\
(\mathrm{km})\end{array}$ & $\begin{array}{l}\text { Source } \\
\text { length } \\
(\mathrm{km})\end{array}$ & $\begin{array}{l}\text { Characteristic } \\
\text { magnitude } \\
\text { (WC94) }\end{array}$ & $\begin{array}{l}\text { Characteristic } \\
\text { magnitude } \\
\text { (HB14) }\end{array}$ & $M_{\max } 1$ & $M_{\max } 2$ & $M_{\max } 3$ \\
\hline Düzce & D1 & 25 & 10.5 & 6.45 & 6.40 & 6.52 & 6.67 & 6.82 \\
\hline Düzce & D2 & 25 & 41 & 7.05 & 7.06 & 7.16 & 7.31 & 7.46 \\
\hline Düzce & $\mathrm{D} 1+\mathrm{D} 2$ & 25 & 51.5 & 7.15 & 7.19 & 7.27 & 7.42 & 7.57 \\
\hline Central Marmara & S4 & 15 & 80 & 7.12 & 7.15 & 7.23 & 7.38 & 7.53 \\
\hline Central Marmara & S5 & 15 & 49.2 & 6.91 & 6.89 & 7.00 & 7.15 & 7.30 \\
\hline Central Marmara & $\mathrm{S} 4+\mathrm{S} 5$ & 15 & 129.2 & 7.33 & 7.41 & 7.47 & 7.62 & 7.77 \\
\hline Ganos/Saros & S6 & 15 & 84 & 7.14 & 7.18 & 7.26 & 7.41 & 7.56 \\
\hline Ganos/Saros & S7 & 15 & 53 & 6.94 & 6.93 & 7.03 & 7.18 & 7.33 \\
\hline Ganos/Saros & $S 6+S 7$ & 15 & 137 & 7.36 & 7.44 & 7.50 & 7.65 & 7.80 \\
\hline Izmit & 3 & 18 & 34.6 & 6.83 & 6.79 & 6.91 & 7.06 & 7.21 \\
\hline Izmit & 2_1 & 18 & 51.6 & 7.01 & 7.01 & 7.11 & 7.26 & 7.41 \\
\hline Izmit & $2 \_2$ & 18 & 30.2 & 6.77 & 6.72 & 6.84 & 6.99 & 7.14 \\
\hline Izmit & $2 \_3$ & 18 & 39.1 & 6.88 & 6.86 & 6.97 & 7.12 & 7.27 \\
\hline Izmit & 1 & 18 & 24.7 & 6.68 & 6.63 & 6.75 & 6.90 & 7.05 \\
\hline Izmit & $3+2 \_1$ & 18 & 86.2 & 7.23 & 7.29 & 7.36 & 7.51 & 7.66 \\
\hline Izmit & $2 \_1+2 \_2$ & 18 & 81.8 & 7.21 & 7.26 & 7.34 & 7.49 & 7.64 \\
\hline Izmit & $2 \_2+2 \_3$ & 18 & 69.3 & 7.14 & 7.17 & 7.25 & 7.40 & 7.55 \\
\hline Izmit & $2 \_3+1$ & 18 & 63.8 & 7.10 & 7.13 & 7.21 & 7.36 & 7.51 \\
\hline Izmit & $3+21+22$ & 18 & 116.4 & 7.37 & 7.45 & 7.51 & 7.66 & 7.81 \\
\hline Izmit & $2 \_1+2 \_2+2 \_3$ & 18 & 120.9 & 7.38 & 7.47 & 7.53 & 7.68 & 7.83 \\
\hline Izmit & $22+23+1$ & 18 & 94 & 7.27 & 7.34 & 7.40 & 7.55 & 7.70 \\
\hline Izmit & $3+2 \_1+2 \_2+2 \_3$ & 18 & 155.5 & 7.50 & 7.61 & 7.65 & 7.80 & 7.95 \\
\hline Izmit & $2 \_1+2 \_2+2 \_3+1$ & 18 & 145.6 & 7.47 & 7.57 & 7.62 & 7.77 & 7.92 \\
\hline Izmit & $3+2 \_1+2 \_2+2 \_3+1$ & 18 & 180.2 & 7.56 & 7.69 & 7.73 & 7.88 & 8.03 \\
\hline Southern Çınarcık & Southern Çınarcık & 18 & 39 & 6.86 & 6.88 & 6.97 & 7.12 & 7.27 \\
\hline Background & - & 18 & - & - & & 6.5 & 6.80 & 7.1 \\
\hline
\end{tabular}

\section{Background zone - smoothed seismicity}

A background source zone of diffused seismicity is utilized to characterize the seismicity that is not associated with the rupture systems described in the previous sections. This additional background source zone represents the seismicity associated with the mapped active faults to the south of Marmara Sea (orange fault lines in Fig. 1a) and the interpretation that even in areas where active faults or distinctive zones of seismicity clusters are not observed, earthquakes can still occur. Figure 1c shows that the spatial distribution of the earthquakes (outside the buffer zones around the rupture systems) is not homogeneous: the density of the events increases significantly around the Geyve-Iznik fault zone. Therefore, defining an areal source zone with homogeneous seismicity distribution would result in the overestimation of the seismic hazard in Istanbul. Instead, the background source is modeled as a source of gridded seismicity where the earthquakes are represented as point or planar fault sources at the centers of evenly spaced grid cells $\left(0.05^{\circ}\right.$ spacing). The truncated exponential magnitude distribution (Eq. 1) is selected to represent the relative frequency of the different magnitude events for this source. In the magnitude recurrence model, spatially uniform $M_{\max }$ and $b$ values and spatially variable $a$ values, or seismicity rates, are defined. The minimum magnitude $\left(M_{\min }\right)$ is again set to $M_{\mathrm{w}}=4.0$ and the $b$ value is taken as 0.81 . The $a$ value for each grid cell was calculated from the maximum likelihood method of Weichert (1980), based on events with magnitudes of 4.0 and larger. The gridded $a$ values were then smoothed by using an isotropic Gaussian kernel with a correlation distance of $10 \mathrm{~km}$ (Frankel, 1995). The smoothed-seismicity rates overlying the earthquakes outside the buffer zones are presented in Fig. 5. Tabulated values of the grid cell coordinates and the seismicity rates are provided in the Supplement. During the calculations of the smoothed seismicity rates, the earthquakes in buffer zones are not included in smoothing (and not doublecounted). The buffer zones are only used to "associate" the earthquakes with the fault zones and collapse the earthquakes to the vertical fault planes. Therefore, the background source and the fault sources can be superposed in the PSHA calculations.

The $M_{\max }$ distribution of the background zone is developed by taking into account the lack of evidence for surface 


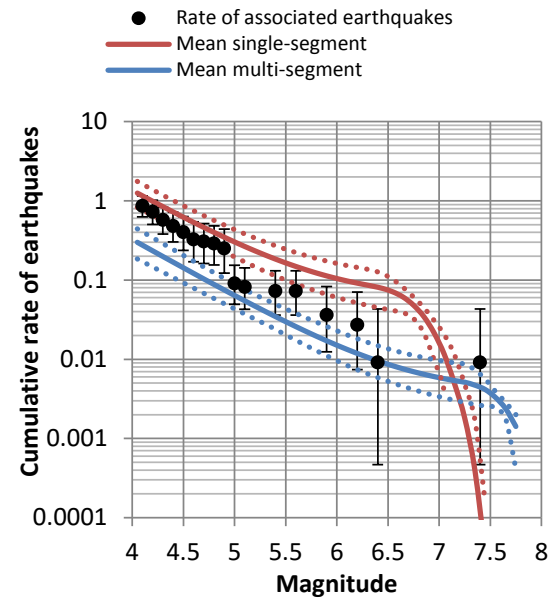

(a)

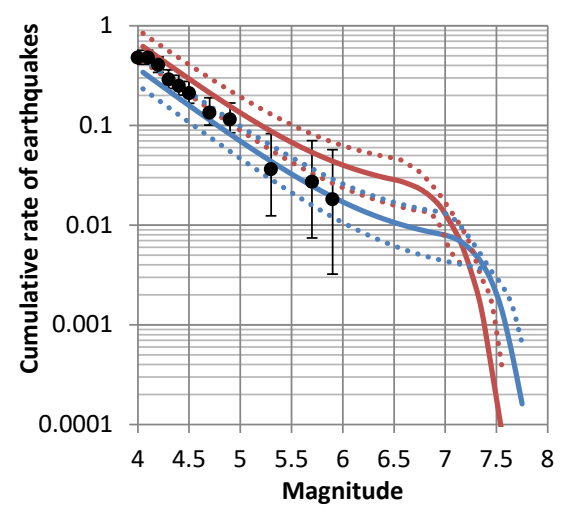

(c)

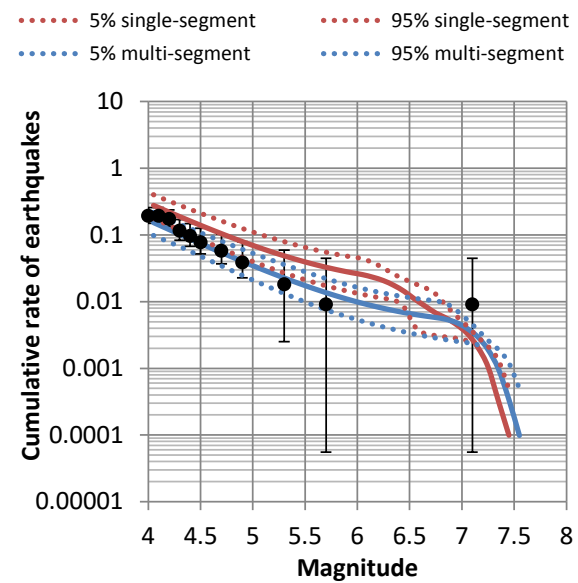

(b)

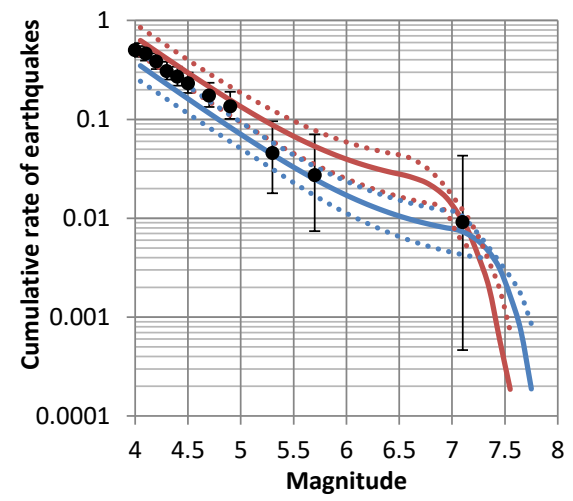

(d)

Figure 6. Mean and fractals of the single-segment and multi-segment rupture scenarios with the cumulative rate of earthquakes associated with the rupture system for (a) Izmit, (b) Düzce, (c) central Marmara, and (d) Ganos/Saros rupture systems. Solid lines are the mean rates and the dashed lines show the 5 and $95 \%$ rates for each rupture scenario.

faulting in the city of Istanbul. So far, no active fault has been reported from the near vicinity of the study area. Similarly, the MTA Active Fault Map of Turkey (Emre et al., 2013) does not contain any active fault in the northern part of the NAFZ between Izmit and Tekirdağ. Moschetti et al. (2015) mentioned that the development of the $M_{\max }$ model for shallow crustal seismicity in the western United States benefits from the large set of regional earthquake magnitudes from the historical and paleoseismic records; however, the background seismicity model accounts for earthquake ruptures on unknown faults; therefore, the $M_{\max }$ distribution must reflect the range of possible magnitudes for these earthquakes. We adopted a similar approach using the fault segments of the southern strand of the NAFZ documented in Murru et al. (2016) and calculated the characteristic magnitude for each segment using Wells and Coppersmith (1994) magnitude-rupture-area relation. Based on the estimations of characteristic magnitude of earthquakes that may occur on the southern strand of the NAFZ, the logic tree for $M_{\max }$ (centered on $M_{\mathrm{w}}=6.8$ ) of the background zone is developed (Table 6). The focal mechanisms of the background source should reflect the tectonic style of the parent region; therefore, a weighted combination of strike-slip (SS, $75 \%$ ), normal (N, 20\%), and reverse (R, 5\%) motions with weights that sum to 1 is assigned to this source (Table 3). A uniform distribution of focal depths between the surface and $18 \mathrm{~km}$ depth is utilized (Emre et al., 2016).

\section{Discussions on the uncertainty involved in the proposed SSC model}

In the proposed SSC model, the uncertainties related to $M_{\max }$, magnitude-rupture-area relations, magnitude recurrence model parameters, and the annual slip rates are considered and included in the logic tree (Supplement). On the other hand, the uncertainty related to the fault geometry such as the uncertainty in segment lengths, fault widths, and dip angles remained unexplored. All rupture sources within each 
rupture system are thought to occur in order to capture the aleatory variability in the extent and potential size of future ruptures. However, the epistemic uncertainty in the potential rupture scenarios are not taken into account since only one set of weights for each rupture scenario is included in the logic tree. In order to compare the epistemic uncertainty in the proposed SSC model with the uncertainty in the earthquake catalog, the SSC model fractals for each rupture source are calculated and the extreme values represented by the single-segment rupture sources and full-span rupture source are presented in Fig. 6 with red and blue sets of curves, respectively. It is notable that the rates of observed earthquakes were used to validate the rupture scenario weights in Fig. 4, aiming to capture a good fit between weighted average rates and the mean rates of observed earthquakes. Figure 6 shows that the uncertainty range sampled by the proposed model is consistent with the rate of earthquakes associated with each rupture system, especially for $M_{\mathrm{w}}<6$ events that have a large sample size.

We would like to emphasize that the SSC model presented here is different to the models proposed by Gülerce and Ocak (2013) and Murru et al. (2016): differences in the fault geometry are minor but the differences in the magnitude recurrence models and the time-dependent probabilities of earthquakes are more significant. Unfortunately, earlier publications did not provide enough information on earthquake rates to do a case-to-case comparison of the earthquake rates proposed herein with the previous works. Our model does not utilize the time-dependent hazard methodologies as in Murru et al. (2016); however, we believe that ongoing research on the paleoseismic recurrence periods (National Earthquake Strategy and Action Plan for 2023, NESAP2023) will provide a substantial contribution in the PSHA practice of Turkey and eventually lead to a change in the hazard estimates. The available paleoseismic data on NAFZ are too few and insufficient to provide meaningful constraints on the "grand inversion" as used in the UCERF3 model for California (Field et al., 2014). Therefore, the proposed model does not include fault-to-fault ruptures that can jump over the boundaries of the defined rupture systems.

\section{Conclusions}

This paper presents details of the SSC model proposed for the PSHA studies in Istanbul. When compared to the previous SSC models developed for this region, significant improvements in the proposed model can be listed as follows: (1) planar seismic sources that account for the most current tectonic information (e.g., updated fault maps) are built, (2) the multi-segment rupture scenarios are systematically utilized in the rupture forecast, (3) buffer zones around the rupture systems are defined to associate the small, moderate, and large-magnitude events with the rupture systems, (4) activity rates for the planar rupture systems are calculated us- ing the geological and geodedic constraints (e.g., slip rate and fault geometry), (5) a balance of the accumulated and released seismic moment is considered in building the magnitude recurrence model, and (6) associated earthquakes are used to test the suitability of the magnitude recurrence model with the instrumental seismicity rates. Even though the rupture systems developed in this study account for the relative rates of small, moderate, and large-magnitude events that can occur on the faults, a background source is defined to represent the small-to-moderate magnitude earthquakes that may take place anywhere in the vicinity of Istanbul and the Marmara Sea. Properties of the rupture systems and background source, the logic tree associated with both of these components, coordinates of the fault segments, and smoothed seismicity rates are fully documented throughout the text and in the Supplement. Therefore, the proposed SSC model can be directly implemented to any of the available PSHA software for the site-specific PSHA analysis in Istanbul. We would like to underline that the geometry and the earthquake rates of the background source may be modified for any application outside the greater Istanbul area. The hazard analyst can incorporate the full rupture model and the complete logic tree provided in this paper into most of the available hazard codes without explicitly calculating the earthquake rates. In the case that the earthquake rate has to be incorporated to the hazard code; the earthquake rates for each branch of the logic tree given in the Supplement can be used.

Data availability. Most of the data related to the seismo-tectonic database are available on the institutional websites. Details of the seismic source model input are provided in the Supplement. No other data set from this article is publicly available.

\section{The Supplement related to this article is available online at https://doi.org/10.5194/nhess-17-2365-2017- supplement.}

Competing interests. The authors declare that they have no conflict of interest.

Special issue statement. This article is part of the special issue "Linking faults to seismic hazard assessment in Europe". It is not associated with a conference.

Acknowledgements. Authors of this manuscript are grateful for the support provided by the Turkish Atomic Energy Authority (TAEK). This work was partially supported by the Pacific Gas \& Electric Company Geosciences Department. The authors are thankful to the guest editors and anonymous reviewers for their insightful comments. 
Edited by: Bruno Pace

Reviewed by: two anonymous referees

\section{References}

Aksoy, M. E., Meghraoui, M., Vallée, M., and Çakır, Z.: Rupture characteristics of the AD 1912 Mürefte (Ganos) earthquake segment of the North Anatolian Fault (western Turkey), Geology, 38, 991-994, https://doi.org/10.1130/G31447.1, 2010.

Aksu, A. E., Calon, T. J., Hiscott, R. N., and Yasar, D.: Anatomy of the North Anatolian Fault Zone in the Marmara Sea, western Turkey: extensional basins above a continental transform, GSA Today, 10, 3-7, 2000.

Akyüz, S., Hartleb, R. D., Barka, A.A, Altunel, E., Sunal, G., Meyer, B., and Armijo, R.: Surface rupture and slip distribution of the 12 November 1999 Düzce earthquake (M7.1), North Anatolian Fault, Bolu, Turkey, B. Seismol. Soc. Am., 92, 61-66, 2002.

Altunel, E., Meghraoui, M., Akyüz, H. S., and Dikbas, A.: Characteristics of the 1912 co-seismic rupture along the North Anatolian Fault Zone (Turkey): implications for the expected Marmara earthquake, Terra Nova, 16, 198-204, https://doi.org/10.1111/j.1365-3121.2004.00552.x, 2004.

Ambraseys, N. N. and Jackson, J. A.: Seismicity of the Sea of Marmara (Turkey) since 1500, Geophys. J. Int., 141, F1-F6, https://doi.org/10.1046/j.1365-246x.2000.00137.x, 2000.

An, L. Y.: Maximum link distance between strike-slip faults: observations and constraints, Pure Appl. Geophys., 150, 19-36, 1997.

Armijo, R., Meyer, B., Navarro, S., King, G., and Barka, A.: Asymmetric slip partitioning in the Sea of Marmara pull-apart: a clue to propagation processes of the North Anatolian Fault?, Terra Nova, 14, 80-86, 2002.

Armijo, R., Pondard, N., Meyer, B., Uçarkus, G., de Lépinay, B. M., Malavieille, J., Dominguez, S., Gustcher, M. A., Schmidt, S., Beck, C., and Cagatay, N.: Submarine fault scarps in the Sea of Marmara pull apart (North Anatolian Fault): implications for seismic hazard in Istanbul, Geochem. Geophy. Geosy., 6, 1-29, https://doi.org/10.1029/2004GC000896, 2005.

Ayhan, M. E., Bürgmann, R., McClusky, S., Lenk, O., Aktug, B., Herece, E., and Reilinger, R. E.: Kinematics of the $M_{\mathrm{W}}=7.2$, 12 November 1999, Düzce, Turkey earthquake, Geophys. Res. Lett., 28, 367-370, 2001.

Barka, A. A. and Kadinsky-Cade, K.: Strike-slip fault geometry in Turkey and its influence on earthquake activity, Tectonics, 7, 663-684, 1988.

Barka, A., Akyüz, H. S., Altunel, E., Sunal, G., Cakir, Z., Dikbas, A., Yerli, B., Armijo, R., Meyer, B., De Chabalier, J. B., and Rockwell, T.: The surface rupture and slip distribution of the August 17, 1999 Izmit earthquake (M7.4), North Anatolian Fault, B. Seismol. Soc. Am., 92, 43-60, 2002.

Brodsky, E. E., Karakostas, V., and Kanamori, H.: A new observation of dynamically triggered regional seismicity: earthquakes in Greece following the August 1999 Izmit, Turkey earthquake, Geophys. Res. Lett., 27, 2741-2744, 2000.

Carton, H., Singh, S. C., Hirn, A., Bazin, S., De Voogd, B., Vigner, A., Ricolleau, A., Cetin, S., Oçakoğlu, N., Karakoc, F., and Sevilgen, V.: Seismic imaging of the three-dimensional architecture of the Çınarcık Basin along the North Anatolian Fault, J. Geophys. Res., 112, B06101, https://doi.org/10.1029/2006JB004548, 2007.

Cosentino, P., Ficarra, V., and Luzio, D.: Truncated exponential frequency-magnitude relationship in earthquake statistics, B. Seismol. Soc. Am., 67, 1615-1623, 1977.

Disaster and Emergency Management Presidency: NESAP 2023. Ulusal Deprem Stratejisi ve Eylem Planı (National Earthquake Strategy and Action Plan), available at: https://www.afad.gov.tr/ upload/Node/4311/files/National_Earthquake_Strategy_Action_ Plan_NESAP_Turkey_20150909103246.pdf, last access: 20 December 2017.

Ellsworth, W. L., Matthews, M. V., Nadeau, R. M., Nishenko, S. P., Reasenberg, P. A., and Simpson, R. W.: A physically-based earthquake recurrence model for estimation of long-term earthquake, Workshop on earthquake recurrence, State of the art and directions for the future, Istituto Nazionale de Geofisica, Rome, Italy 1999, 22-25, 1999.

Emre, Ö., Duman, T. Y., Özalp, S., Elmacı, H., Olgun, Ş., and Şaroğlu, F.: Active fault map of Turkey, Special Publication, Series 30, General Directorate of Mineral Research and Exploration (MTA), Ankara, 2013.

Emre, Ö., Duman, T. Y., Özalp, S., Şaroğlu, F., Olgun, Ş., Elmacı, H., and Çan, T.: Active fault database of Turkey, B. Earthq. Eng., 1-47, 2016.

Erdik, M., Demircioglu, M., Sesetyan, K., Durukal, E., and Siyahi, B.: Earthquake hazard in Marmara region, Turkey, Soil Dyn. Earthq. Eng., 24, 605-631, 2004.

Ergintav, S., Reilinger, R. E., Çakmak, R., Floyd, M., Cakir, Z., Doğan, U., King, R. W., McClusky, S., and Özener, H.: Istanbul's earthquake hot spots: geodetic constraints on strain accumulation along faults in the Marmara Seismic Gap, Geophys. Res. Lett., 41, 5783-5788, https://doi.org/10.1002/2014GL060985, 2014.

Field, E. H., Dawson, T. E., Felzer, K. R., Frankel, A. D., Gupta, V., Jordan, T. H., Parsons, T., Petersen, M. D., Stein, R. S., Weldon, R. J., and Wills, C. J.: Uniform California earthquake rupture forecast, version 2 (UCERF 2), B. Seismol. Soc. Am., 99, 2053-2107, 2009.

Field, E. H., Arrowsmith, R. J., Biasi, G. P., Bird, P., Dawson, T. E., Felzer, K. R., Jackson, D. D., Johnson, K. M., Jordan, T. H., Madden, C., and Michael, A. J.: Uniform California earthquake rupture forecast, version 3 (UCERF 3) - The time-independent model, B. Seismol. Soc. Am., 104, 1122-1180, 2014.

Flerit, F., Armijo, R., King, G. C. P., Meyer, B., Barka, A.: Slip partitioning in the Sea of Marmara pull-apart determined from GPS velocity vectors, Geophys. J. Int., 154, 1-7, https://doi.org/10.1046/j.1365-246X.2003.01899.x, 2003.

Flerit, F., Armijo, R., King, G., and Meyer, B.: The mechanical interaction between the propagating North Anatolian Fault and the back-arc extension in the Aegean, Earth Planet. Sc. Lett., 224 347-362, 2004.

Frankel, A.: Mapping seismic hazard in the central and eastern United States, Seismol. Res. Lett., 66, 8-21, https://doi.org/10.1785/gssrl.66.4.8, 1995.

Gülerce, Z. and Ocak, S.: Probabilistic seismic hazard assessment of eastern Marmara Region, B. Earthq. Eng., 11, 1259-1277, https://doi.org/10.1007/S10518-013-9443-6, 2013.

Gülerce, Z. and Vakilinezhad, M.: Effect of seismic source model parameters on the probabilistic seismic hazard assessment results: a case study for North Anatolian Fault Zone, B. Seismol. 
Soc. Am., 105, 2808-2822, https://doi.org/10.1785/0120150101, 2015.

Gurbuz, C., Aktar, M., Eyidogan, H., Cisternas, A., Haessler, H., Barka, A., Ergin, M., Türkelli, N., Polat, O., Üçer, S. B., and Kuleli, S.: The Seismotectonics of the Marmara region (Turkey): results from a microseismic experiment, Tectonophysics, 316, 117, 2000.

Gutenberg, B. and Richter, C. F.: Frequency of earthquakes in California, Bull. Seismol. Soc. Am., 34, 185-188, 1944.

Hanks, T. C. and Bakun, W. H.: $M-\log A$ models and other curiosities, B. Seismol. Soc. Am., 104, 2604-2610, 2014

Harris, R. A., Dolan, J. F., Hartleb, R., and Day, S. M.: The 1999 Izmit, Turkey, earthquake: a 3-D dynamic stress transfer model of intra-earthquake triggering, B. Seismol. Soc. Am., 92, 245255, 2002

Hecker, S., Abrahamson, N. A., and Wooddell, K. E.: Variability of displacement at a point: implications for earthquake-size distribution and rupture hazard on faults, B. Seismol. Soc. Am., 103, 651-674, https://doi.org/10.1785/0120120159, 2013.

Hergert, T. and Heidbach, O.: Slip-rate variability and distributed deformation in the Marmara Sea Fault System, Nat. Geosci., 3, 132, https://doi.org/10.1038/NGEO739, 2010.

Hergert, T., Heidbach, O., Bécel, A., and Laigle, M.: Geomechanical model of the Marmara Sea region - I. 3-D contemporary kinematics, Geophys. J. Int., 185, 1073-1089, 2011.

Imren, C., Le Pichon, X., Rangin, C., Demirbağ, E., Ecevitoğlu, B., and Görür, N.: The North Anatolian Fault within the Sea of Marmara: a new interpretation based on multi-channel seismic and multi-beam bathymetry data, Earth Planet. Sc. Lett., 186, 143158, https://doi.org/10.1016/S0012-821X(01)00241-2, 2001.

Kalafat, D., Güneş, Y., Kekovali, K., Kara, M., Deniz, P., and Yılmazer, M.: Bütünleştirilmiş Homojen Türkiye Deprem Kataloğu (1900-2010; $M \geq 4.0$ ), Boğaziçi Üniversitesi, Kandilli Rasathanesi ve Deprem Araştırma Enstitüsü, İstanbul, Yayın No: 1049, 640, Istanbul, 2011.

Kalkan, E., Gulkan, P., Yilmaz, N., and Celebi, M.: Reassessment of probabilistic seismic hazard in the Marmara region, B. Seismol. Soc. Am., 99, 2127-2146, https://doi.org/10.1785/0120080285, 2009.

Laigle, M., Becel, A., de Voogd, B., Hirn, A., Taymaz, T., and Ozalaybey, S.: A first deep seismic survey in the Sea of Marmara: deep basins and whole crust architecture and evolution, Earth Planet. Sc. Lett., 270, 168-179, 2008.

Langridge, R. M., Stenner, H. D., Fumal, T. E., Christofferson, S. A., Rockwell, T. K., Hartleb, R. D., Bachhuber, J., and Barka, A. A.: Geometry, slip distribution, and kinematics of surface rupture on the Sakarya Fault segment during the $17 \mathrm{Au}-$ gust 1999 Izmit, Turkey, B. Seismol. Soc. Am., 92, 107-125, 2002.

Lettis, W., Bachhuber, J., Witter, R., Brankman, C., Randolph, C. E., Barka, A., Page, W. D., and Kaya, A.: Influence of releasing stepovers on surface fault rupture and fault segmentation: examples from the 17 August 1999 Izmit earthquake on the North Anatolian Fault, Turkey, B. Seismol. Soc. Am., 92, 19-42, 2002.

Le Pichon, X., Sengör, A. M. C., Demirbag, E., Rangin, C., Imren, C., Armijo, R., Görür, N., Çagatay, N., Mercier de Lepinay, B., Meyer, B., Saatçilar, R., and Tok, B.: The active main Marmara Fault, Earth Planet. Sc. Lett., 192, 595-616, 2001.
Le Pichon, X., Chamot-Rooke, N., Rangin, C., and Sengor, A. M. C.: The North Anatolian Fault in the Sea of Marmara, J. Geophys. Res., 108, 2179, https://doi.org/10.1029/2002JB001862, 2003.

McClusky, S., Balassanian, S., Barka, A., Demir, C., Ergintav, S. Georgiev, I., Gurkan, O., Hamburger, M., Hurst, K., Kahle, H., and Kastens, K.: Global positioning system constraints on plate kinematics and dynamics in the Mediterranean and Caucasus, J. Geophys. Res., 105, 5685-5719, https://doi.org/10.1029/1999JB900351, 2000.

McNeill, L. C., Mille, A., Minshull, T. A., Bull, J. M., Kenyon, N. H., and Ivanov, M.: Extension of the North Anatolian Fault into the North Aegean Trough: evidence for transtension, strain partitioning, and analogues for Sea of Marmara Basin models, Tectonics, 23, TC2016, https://doi.org/10.1029/2002TC001490, 2004.

Meade, B. J., Hager, B. H., McClusky, S. C., Reilinger, R. E., Ergintav, S., Lenk, O., Barka, A., and Ozener, H.: Estimates of seismic potential in the Marmara Sea region from block models of secular deformation constrained by global positioning system measurements, B. Seismol. Soc. Am., 92, 208-215, https://doi.org/10.1785/0120000837, 2002.

Mert, A., Fahjan, Y. M., Hutchings, L. J., and Pinar, A.: Physically based probabilistic seismic hazard analysis using broadband ground motion simulation: a case study for the Prince Islands Fault, Marmara Sea, Earth Planets Space, 68, 146, https://doi.org/10.1186/s40623-016-0520-3, 2016.

Mignan, A., Danciu, L., and Giardini, D.: Reassessment of the maximum fault rupture length of strike-slip earthquakes and inference on $M_{\max }$ in the Anatolian Peninsula, Turkey, Seismol. Res. Lett., 86, 890-900, 2015.

Moschetti, M. P., Powers, P. M., Petersen, M. D., Boyd, O. S., Chen, R., Field, E. H., Frankel, A. D., Haller, K. M., Harmsen, S. C., Mueller, C. S., and Wheeler, R. L.: Seismic source characterization for the 2014 update of the US national seismic hazard model, Earthq. Spectra, 31, S31-S57, 2015.

Muller, J. R. and Aydin, A.: Using mechanical modelling to constrain fault geometries proposed for the northern Marmara Sea, J. Geophys. Res.-Sol. Ea., 110, B03407, https://doi.org/10.1029/2004JB003226, 2005.

Murru, M., Akinci, A., Falcone, G., Pucci, S., Console, R., and Parsons, T.: $M \geq 7$ earthquake rupture forecast and time-dependent probability for the Sea of Marmara region, Turkey, J. Geophys. Res.-Sol. Ea., 121, 2679-2707, https://doi.org/10.1002/2015JB012595, 2016.

Okay, A. I., Demirbağ, E., Kurt, H., Okay, N., and Kuşçu, I.: An active, deep marine strike-slip basin along the North Anatolian Fault in Turkey, Tectonics, 18, 129-147, 1999.

Okay, A. I., Tüysüz, O., and Kaya Ş.: From transpression to transtension: changes in morphology and structure around a bend on the North Anatolian Fault in the Marmara region, Tectonophysics, 391, 259-282, https://doi.org/10.1016/j.tecto.2004.07.016, 2004.

OYO: Production of microzonation report and maps - on European side (south), Final Report to Istanbul Metropolitan Municipality, available at: http://www.preventionweb.net/files/43040_paulanu. pdf (last access: 20 December 2017), 2007.

Örgülü, G. and Aktar, M.: Regional moment tensor inversion for strong aftershocks of the August 17, 1999 Izmit 
earthquake $\left(M_{\mathrm{W}}=7.4\right)$, Geophys. Res. Lett., 28, 371-374, https://doi.org/10.1029/2000GL011991, 2001.

Özalaybey, S., Ergin, M., Aktar, C., Tapırdamaz, Biçmen, F., and Yörük, A.: The 1999 İzmit earthquake sequence in Turkey: seismological and tectonic aspects, B. Seismol. Soc. Am., 92, 376386, 2002

Parsons, T.: Recalculated probability of $M>7$ earthquakes beneath the Sea of Marmara, Turkey, J. Geophys. Res., 109, B05304, https://doi.org/10.1029/2003JB002667, 2004.

Pinar, A., Kuge, K., and Honkura, Y.: Moment tensor inversion of recent small to moderate sized earthquakes: implications for seismic hazard and active tectonics beneath the Sea of Marmara, Geophys. J. Int., 153, 133-145, https://doi.org/10.1046/j.1365246X.2003.01897.x, 2003.

Pondard, N., Armijo, R., King, G. C., Meyer, B., and Flerit, F.: Fault interactions in the Sea of Marmara pull-apart (North Anatolian Fault): earthquake clustering and propagating earthquake sequences, Geophys. J. Int., 171, 1185-1197, https://doi.org/10.1111/j.1365-246X.2007.03580.x, 2007.

Reasenberg, P.: Second-order moment of central California seismicity, 1969-1982, J. Geophys. Res., 90, 5479-5495, https://doi.org/10.1029/JB090iB07p05479, 1985.

Reilinger, R., McClusky, S., Vernant, P., Lawrence, S., Ergintav, S., Cakmak, R., Özener, H., Kadirov, F., Guliev, İ., Stepanyan, R., Nadariya, M., Galaktion, H., Mahmoud, S., Sakr, K., ArRajehi, A., Paradissis, D., Al-Aydrus, A., Prilepin, M., Guseva, T., Evren, E., Dmitrotsa, A., Filikov, S. V., Gomez, F., Al-Ghazzi, R., and Karam, G.: GPS constraints on continental deformation in the Africa-ArabiaEurasia continental collision zone and implications for the dynamics of plate interactions, J. Geophys. Res., 111, B05411, https://doi.org/10.1029/2005JB004051, 2006.

Şaroğlu, F., Emre, O., and Kuşcu, I.: Active fault map of Turkey, General Directorate of Mineral Research and Exploration, Ankara, Turkey, 1992.

Schwartz, D. P. and Coppersmith, K. J.: Fault behaviour and characteristic earthquakes: examples from the Wasatch and San Andreas Fault zones, J. Geophys. Res., 89, 5681-5698, 1984

Segall, P. and Pollard, D. D.: Mechanics of discontinuous faults, J. Geophys. Res., 85, 4337-4350, 1980.
Şengör, A. C., Grall, C., İmren, C., Le Pichon, X., Görür, N., Henry, P., Karabulut, H., and Siyako, M.: The geometry of the North Anatolian Transform Fault in the Sea of Marmara and its temporal evolution: implications for the development of intracontinental transform faults, Can. J. Earth Sci., 51, 222-242, 2014.

Sesetyan, K., Demircioglu, M. B., Duman, T. Y., Can, T., Tekin, S., Azak, T. E., and Fercan, Ö. Z.: A probabilistic seismic hazard assessment for the Turkish territory - part I: The area source model, B. Earthq. Eng., 1-31, 2016.

Shi, Y. and Bolt, B. A.: The standard error of the magnitudefrequency $b$ value, B. Seismol. Soc. Am., 72, 1677-1687. 1982.

Stein, R. S., Barka, A. A., and Dieterich, J. H.: Progressive failure on the North Anatolian Fault since 1939 by earthquake stress triggering, Geophys. J. Int., 128, 594-604, 1997.

Weichert, D.: Estimation of the earthquake recurrence parameters for unequal observation periods for different magnitudes, B. Seismol. Soc. Am., 70, 1337-1346, 1980.

Wells, D. L. and Coppersmith, K. J.: New empirical relationships among magnitude, rupture length, width, area and surface displacement, B. Seismol. Soc. Am., 84, 974-1002, 1994.

Wesnousky, S. G.: Seismological and structural evolution of strike-slip faults, Nature, 335, 340-343, https://doi.org/10.1038/335340a0, 1988.

Wiemer, S.: A software package to analyse seismicity: ZMAP, Seismol. Res. Lett., 72, 373-382, https://doi.org/10.1785/gssrl.72.3.373, 2001.

Wong, H. K., Lüdmann, T., Ulug, A., and Görür, N.: The Sea of Marmara: a plate boundary sea in an escape tectonic regime, Tectonophysics, 244, 231-250, https://doi.org/10.1016/00401951(94)00245-5, 1995.

Working Group on California Earthquake Probabilities (WGCEP2003): Earthquake probabilities in the San Francisco Bay Region: 2002-2031, Open-File Rept. 03-214, US Geol. Soc., USA, 2003.

Yaltirak, C.: Tectonic evaluation of Marmara Sea and its surroundings, Mar. Geol., 190, 439-529, https://doi.org/10.1016/S00253227(02)00360-2, 2002.

Youngs, R. R. and Coppersmith, K. J.: Implications of fault slip rates and earthquake recurrence models to probabilistic seismic hazard estimates, B. Seismol. Soc. Am., 75, 939-964, 1985. 